\title{
An AHP Framework to Evaluate Barriers and Potential Tensions to Green Supply Chain Management in the Food and Beverage Industry
}

\author{
Ahmed Esmail Mohamed \\ University of Southern Denmark, Campusvej 55, DK-5230 Odense M, Denmark \\ Tel: +4560471912 E-mail: Ahmed.esmail.mohamed19@gmail.com
}

\begin{abstract}
With an increasing awareness of climate change and the need for sustainable processes, a growing number of studies have addressed green supply chain management (GSCM), its drivers, barriers, and implementation frameworks. However, despite the importance of environmental practices, industries are reluctant to implement GSCM activities, as many obstacles can arise while initiating GSCM in traditional supply chain management (TSCM). The previous literature review indicated substantial research on the barriers that hinder the adoption of green activities. To the best of our knowledge, no previous research has assessed the tensions and conflicts that may arise among collaborating actors, which can also hinder the adoption of environmental business practices. In particular, there is a notable gap in research that investigates the green- supply-chain issues in the Egyptian food and beverage manufacturing sector. In this paper, we went a step ahead to investigate these issues and to explore how GSCM barriers cause tensions among collaborating actors. Hence, the purpose of this paper is to investigate the barriers and tensions that impede the implementation of GSCM in the Egyptian food and beverage industry (FBI). In our methodology, we targeted three large food and beverage multinational companies located in Egypt. Barriers and types of tensions were identified through the literature review. Data collection consisted of three phases. For the primary source of data, a qualitative method was utilized for semi-structured interviews, followed by a questionnaire survey. Furthermore, a decision group was formed to collect and validate the data. Using the analytic hierarchy process (AHP), this study categorised the identified barriers based on the relevant type of tension and explored how such barriers can create tension among various stakeholders. Thirty-nine barriers and 11 types of tension were identified through the literature review and discussion with experts. Of the total number of identified barriers, 18 were identified as common. Based on the AHP results, the category of economic tensions had the most importance. The barrier related to inflation and the currency exchange rate was the most significant among the 18 barriers and was the main driver of economic tensions. Our findings suggest that the economic instability of countries can affect the implementation of GSCM. This is the first study that combines barriers and tensions among stakeholders as impediments toward adopting green environmental practices. This study provides a new approach to the literature, giving insight into the tensions that could delay or prevent the adoption of green business activities, an approach that could be a scientific breakthrough for upcoming studies. Finally, this study can help the Egyptian FBI to identify the main issues that could hinder the transition from TSCM to GSCM.

Keywords: Green supply chain management; analytical hierarchy process; barrier analysis; tensions; food and beverage industry

DOI: $10.7176 / \mathrm{EJBM} / 13-6-01$

Publication date:March $31^{\text {st }} 2021$
\end{abstract}

\section{Introduction}

Global warming, the scarcity of natural resources and many other phenomena have forced governments and international bodies to be more serious about the sustainability of the environment. The rapid increase in demand in the manufacturing sector has led to an increase in supply chain activities, which is usually associated with waste generation, pollution, depletion of natural resources, climate problems and disruptions in the eco-system (Kamalakanta Muduli et al., 2013). Due to an increase in customer and government awareness, environmental sustainability has become a key area of focus on recent business agendas (Ghadge et al., 2017; Shohan et al., 2020). Thus, greening the supply chain is increasingly becoming a concern for many organisations as they are beginning to realise that environmental management is a key strategy that has the potential to have a lasting impact on organisational performance (Diabat \& Govindan, 2011). The main objective of green initiatives is to help organisations reduce pollution and protect the environment (Rahman et al., 2019). In this regard, the term green supply chain management (GSCM) has become increasingly popular in the last few years as an area of research interest. GSCM has emerged as an important organisational philosophy to achieve profit and market share goals by reducing environmental risks and impact while improving the ecological efficiency of these organisations and their partners (Diabat et al., 2013; Qinghua Zhu et al., 2008). Therefore, companies are seeking to implement green practices in their businesses not only because of concerns about environmental sustainability but also to improve their overall performance, develop a competitive advantage and enhance their image (Ghadge et al., 2017).

Greening the supply chain starts with both external and internal pressure from various stakeholders. These 
pressures demand that companies change their traditional practices to more environmentally friendly activities. Consequently, it is necessary to identify the motivators or drivers of implementing GSCM to understand what drives organisations to green their operations. Identified drivers can then help to successfully implement GSCM practices in organisations that have not yet done so. Incorporating green activities into traditional supply chain operations is challenging. While initiating GSCM in TSCM, many obstacles can arise that can lead to negative effects. These obstacles that block or prevent the implementation of GSCM are known as barriers, and industries must equip themselves to eliminate them. Moreover, GSCM implementation can be complicated, as it requires collaboration from partners across the entire supply chain (Liu et al., 2020). However, when implementing green practices, no process can be managed in isolation. Thus, tensions and conflicts can also arise from integrating environmental activities into business practices, and organisations may experience tensions and negative consequences related to GSCM implementation among various stakeholders.

There are differences between developed and developing countries in levels of GSCM implementation as well as in information about green practices. Green supply chain initiatives are famous in developed countries (Chan et al., 2012; Rahman et al., 2019). However, developing countries more often struggle with the implementation of new strategies, especially with sustainable activities (Govindan et al., 2020). Those struggles are primarily related to such areas as lack of knowledge, lack of regulations and lack of transparency.

Additionally, the literature has shown that the green concept continues to be under researched in the manufacturing sectors of developing countries (Tseng et al., 2019; Tumpa et al., 2019; Uddin et al., 2019), especially in the Middle East and Africa (Elbarky \& Elzarka, 2015). Manufacturing processes consume a significant amount of resources and usually energy-intensive (Liu et al., 2020). The literature review revealed that studies have addressed GSCM barriers in only a few kinds of manufacturing industries, such as the electronic sector (Abdulrahman et al., 2014; Sirisawat \& Kiatcharoenpol, 2018), the automobile industry (Balon et al., 2016; Sunil Luthra et al., 2011), fastener manufacturing industries (Al Zaabi et al., 2013), the leather industry (M. A. Moktadir et al., 2018; Uddin et al., 2019), petrochemical industries (Mehrabi et al., 2012), mining industries (Barve \& Muduli, 2013), food packaging industries (Wang et al., 2016), electrical power supply manufacturing industries (Movahedipour et al., 2017) and the plastics industry (S. Luthra et al., 2016; Mathiyazhagan et al., 2016).

As far as we are aware, no study has been conducted identifying GSCM obstacles in the food and beverage manufacturing sector in a developing country. The FBI consumes a lot of resources that have a noticeable environmental impact (Grekova et al., 2014). This manufacturing industry faces a great deal of pressure to reduce its environmental impact, not only in developed countries, but also in developing countries (Grekova et al., 2014). Therefore, this study will explore and analyse the obstacles to GSCM adoption in the context of a developing country's food and beverage manufacturing sector. The study uses Egypt, a Middle Eastern African country, as an example of a developing country to investigate the obstacles to GSCM implementation. In a developing country such as Egypt, the focus is only on cost reduction - usually without any thought to environmental practices (Elbarky \& Elzarka, 2015). Environmental practices are not widely utilised in the manufacturing sector of Egypt. Further, there are few or no significant studies on GSCM in Egypt. In Egypt, the manufacturing industries pay scarcely any attention to environmental pollution. Because of global pressure, investor pressure and the increasing awareness of society, the manufacturing industries of Egypt have started to incorporate green activities in their operations and supply chain. However, these manufacturing industries face many obstacles to fully implementing GSCM activities. Hence, rigorous research is required to determine the obstacles hindering the adoption of GSCM activities in the food and beverage industry of Egypt. The proposed study is one of the first to be conducted in the Egyptian context analysing GSCM barriers in the food and beverage manufacturing sectors. This is the first motivation of this study.

A review of the existing literature indicates that researchers have focused on GSCM-related barriers (Abhijit Majumdar \& Sinha, 2019; Wooi \& Zailani, 2010), drivers for green initiatives (Lee, 2008) and challenges associated with the implementation of GSCM (Barve \& Muduli, 2013). It has been noted that tensions that emerge from contradictory goals and interests among collaborating actors concerning GSCM implementation have not been given appropriate attention. Tension is usually seen as a negative consequence that can destroy business relationships and network partnerships (Tura et al., 2019). Moving towards the green era calls for organisational change management, which requires a transition from unsustainable to sustainable practices. The transition from traditional business activities to new business strategies is usually accompanied by tensions among various stakeholders (Hahn et al., 2015). Some studies have addressed emerging tensions in business networks in the context of sustainability, but they have focused only on tensions between sustainability's three dimensions: social, economic and environmental (Slawinski \& Bansal, 2015; Van der Byl \& Slawinski, 2015). Currently, green practices should be a part of business strategy, but their adoption is impeded by barriers that lead to multiple tensions among the actors in the supply chain. In the context of GSCM implementation, tensions between collaborating partners can hinder the implementation of green practices. Furthermore, formal research focusing on tensions that may occur among various collaborating actors for GSCM adoption is not exhaustive. Therefore, this study will investigate barriers to GSCM and explore how such barriers can lead to multiple tensions among 
different collaborating partners. In addition, this study combines barriers and tensions as impediments to environmental practices and provides a concrete theoretical framework for the development of future research. This is the second motivation of this study.

Evaluation related to GSCM barriers is a multidimensional and multicriteria decision problem involving numerous and conflicting choices that require an appropriate tool to support the decision (Rahman et al., 2019; Wang et al., 2016). According to the literature, many multi-criteria decision making (MCDM) tools, such as DEMATEL, ANP, TOPSIS and the analytical hierarchy process (AHP), have been used to support the evaluation and ranking of barriers and alternatives (Govindan et al., 2014; Govindan et al., 2016; Jasneet Kaur et al., 2018; Sirisawat \& Kiatcharoenpol, 2018). This study seeks to identify and rank the barriers to GSCM implementation using a well-known MCDM. AHP is considered one of the most important methods in MCDM (Bouzon et al., 2016; Sunil Luthra et al., 2013; Abhijit Majumdar \& Sinha, 2019). AHP depends on the competence of experts to develop applicable solutions to problems, and it is quite reliable because the pairwise comparison makes procedures impervious to comparison inaccuracy (Abhijit Majumdar \& Sinha, 2019). Additionally, AHP integrates a vital tool for checking the consistency of evaluations of the experts' judgments, therefore reducing decisionmaking bias (Samaras et al., 2014). For the above-mentioned reasons, the AHP technique has been utilized for this study.

The objectives of this research are summarized as follows:

- Identify barriers to GSCM implementation in the context of developing countries' manufacturing sectors.

- Identify potential types of tensions that may arise between various collaborating actors in the context of GSCM implementation.

- Categorise the identified barriers by their relevant types of tension using the AHP technique and investigate how GSCM barriers can lead to multiple tensions among different collaborating actors.

This paper differs from previous studies in several aspects. First, the research focuses on GSCM barriers and the tensions that may arise. Second, the chosen approach combines barriers and tensions as impediments to environmental practices and provides a concrete theoretical framework for the development of future research. Third, the originality of this paper relies on the fact that no previous research was found that addressed tensions that may arise among different stakeholders that could delay or prevent the implementation of green activities. Thus, in this study we have attempted to provide new insight for future studies into the barriers and tensions related to GSCM implementation. This paper is illustrating both the barriers and tensions and their complex interrelationships that affect the adoption of any new strategy. Thus, the objectives of this work are to identify barriers and tensions to implement GSCM through a detailed literature review and to categorize these barriers based on their relevant type of tensions using AHP. For this purpose, in this paper we examine three multinational food and beverage companies located in Egypt.

The remainder of the paper is structured in six sections. Section 2 reviews the concept of GSCM, barriers related to GSCM implementation in developing countries' manufacturing sectors, potential types of tensions that could arise among collaborating actors while implementing new business strategies and the research gap. Section 3 briefly describes the problem description that will be addressed in this study. Section 4 describes the solution methodology. The results and discussion will be presented in Section 5. The managerial implication and theoretical implication will be discussed in section 6. Finally, the conclusion, limitations and future directions are elaborated on in Section 7.

\section{Literature review}

The literature review focuses on GSCM, existing works on barriers to GSCM implementation, types of tensions that may arise between different collaborating actors and the research gap.

\subsection{Green Supply Chain Management (GSCM)}

The supply chain is considered one of the primary components of operation management and has a tangible effect on the environment, including emissions, pollution and being responsible for health hazards to the community (Tseng et al., 2019). The integration of environmental issues into supply chain management (SCM) practices has itself evolved into a separate and growing field because of global environmental concerns (Sarkis et al., 2011; Wu $\& \mathrm{Li}, 2019)$. The greening of the supply chain is increasingly a concern for many organizations as they recognize that environmental management is a key strategic issue that can have a lasting impact on organizational performance (Diabat \& Govindan, 2011). The term GSCM has grown in the last few years to become an increasingly popular research area. The field of GSCM has emerged as an important philosophy to help an organization achieve profit and market share goals by reducing environmental risks and impact while improving the ecological efficiency of these organizations and their partners (Diabat et al. (2013); Qinghua Zhu et al. (2008). Rao and Holt (2005) considered GSCM to be innovative supply chain management because it promotes efficiency and synergy among business partners and is expected to improve the image, competitive advantage and economic performance of organizations. GSCM is expressed as SCM with environmentally friendly materials combined into 
every aspect of the supply chain. Sarkis (2011) defined GSCM as "integrating environmental concerns into the inter-organizational practices of SCM, including reverse logistics". The concept of GSCM implies the integration of environmental considerations within traditional SCM, including product design; procurement; supplier selection, manufacturing, and production processes; logistics and the delivery of the final product to the consumer; and end-of-life management of the product (Emmett \& Sood, 2010). According to Hervani et al. (2005), GSCM is defined as the summation of green purchasing, green manufacturing/materials management, green distribution/marketing and reverse logistics. Srivastava (2007) argued that GSCM has its roots in SCM and environmental management literature and can be defined as "integrating environmental thinking into supply chain management, including product design, material sourcing, and selection, manufacturing processes, delivery of the final product to the consumers as well as end-of-life management of the product after its useful life".

Manufacturing industries are facing both local and global pressure to implement green practices in their operations and supply chains (Sunil Luthra et al., 2013; Qinghua Zhu et al., 2012). GSCM is the way to integrate environmental activities into traditional supply chain practices, ensuring less pollution and less waste (Rahman et al., 2019). GSCM is not only considered an enabler of environmental enhancement, but it also improves the economic performance of an organization (Y. Ali et al., 2020; Rao \& Holt, 2005; Tumpa et al., 2019; Yang et al., 2020). According to A. Ali and Bentley (2015), GSCM can help improve productivity, employee morale, reputation and therefore the overall performance of an organization. Abdel-Baset et al. (2019) concluded that GSCM has helped decrease negative effects (air, water and land pollution) and garbage of resources (energy, materials and products) of manufacturing sectors. In addition, Seman et al. (2019) noted that GSCM can speed up the green innovation of companies, which could render the manufacturing process more effective with regard to the environment.

Research topics related to GSCM have mainly focused on defining the scope of the green supply chain (Ahi \& Searcy, 2013), activities of the green supply chain (Qinghua Zhu et al., 2005), the drivers that motivate the adoption of the green supply chain (Diabat \& Govindan, 2011) and the barriers and challenges that hinder its implementation (Tumpa et al., 2019).

Numerous obstacles hinder the implementation of GSCM (Govindan et al., 2014; Kamalakanta Muduli et al., 2013). Developing countries continue to investigate the barriers that hinder environmental practices and still believe that focusing on environmental sustainability will have negative effects on economic sustainability because of the associated costs. Eliminating all the barriers is a difficult task, but identifying the dominant factors could help companies find appropriate solutions and make the right decisions. With a clear understanding of the barriers, organizations can determine their weak areas and implement strategies to improve those areas, which will improve the effectiveness of the green practices.

The terms sustainability and green have been popularized and have become important research topics. The concept of sustainability includes understanding the environmental impact of economic activity, ensuring that fundamental human needs are met, securing the conservation of nonrenewable resources and seeking to ensure intergenerational equity (Bansal \& DesJardine, 2014; Carter \& Rogers, 2008; Aymen Sajjad et al., 2019). Carter and Rogers (2008) suggested that organizational sustainability is an intersection of three dimensions: the natural environment, society and economic performance. The authors' findings correspond to the idea of the triple bottom line, which Elkington (1998) developed. However, implementing sustainability in TSCM is usually associated with multiple tensions when at least two of the three goals of sustainability are conflicting (Van der Byl \& Slawinski, 2015), which indicates the complexity of sustainability because of tensions and conflicts that may occur between economic, social and environmental goals (Hahn et al., 2015). Because of emerging needs, industries are prioritizing economic dimensions and paying less attention to environmental sustainability. Sustainability tensions often occur due to conflicts among the goals and requirements of stakeholders. A few studies and other research are being conducted on the concept of tensions in business sustainability and how they could affect the implementation of an organization's sustainability (Hahn et al., 2015; Slawinski \& Bansal, 2015; Van der Byl \& Slawinski, 2015). However, most of these studies have been conducted in the context of sustainability, especially with regard to tensions related to sustainability's three dimensions (economic, social and environmental). No previous study has investigated tensions around GSCM implementation. Tensions, which can be internal or external, can impede the implementation and achievement of any new strategy. In the context of GSCM, tensions among collaborating actors can hinder the implementation of green practices. Hence, it is important to identify and understand the tensions that can occur and find a way to address or at least reduce their effects. Therefore, in this paper, tensions surrounding GSCM implementation will be investigated to understand how they serve as obstacles to GSCM implementation in the context of the Egyptian food and beverage industry. Accordingly, with the increasing attention paid to environmental protection globally, it is essential that the Egyptian manufacturing sector implement green practices as a part of their operation strategy to keep them competitive in the market.

\subsection{Barriers to Implementing GSCM in Developing Countries' Manufacturing Sectors}

Although several factors drive industries to adopt environmentally sustainable practices, some forces hinder the 
motivation of organizations to implement GSCM. This suggests that moving towards a greener era is a complex and wide-ranging task (Da Silva et al., 2018; Mathiyazhagan et al., 2013). Although manufacturing industries may understand the importance of environmental initiatives, those initiatives may be difficult to put into practice because of hurdles (Carvalho et al., 2020). Because implementing environmental practices in the manufacturing sector of some developed nations is mandatory, green activities are spread widely in the manufacturing sector of these countries. However, green practices are not widely utilized in the manufacturing sectors of developing countries. Hence, this section covers the literature on GSCM barriers with a focus on developing countries' manufacturing sectors. Barriers limit the ability of companies to adopt green concepts and negatively impact GSCM adoption. Manufacturing industries face many barriers while implementing GSCM, and it is not an easy task to eliminate all of them; however, if the dominant barrier is identified, it can be addressed (Soda et al., 2017). Identifying the barriers to GSCM implementation can lead to a solution that industrial decision makers can use to launch action plans to change TSCM to GSCM smoothly (Rahman et al., 2019). Hence, industries must identify the barriers that pose the biggest obstacles because identifying and assessing the impact of these barriers on green practices could help industries prioritize the necessary steps to eliminate or mitigate these obstacles (S. Balasubramanian \& Shukla, 2017; Mathiyazhagan et al., 2016).

In recent years, researchers have examined the challenges that hinder organizations from adopting green practices (Rahman et al., 2019; Tumpa et al., 2019). Many studies have confirmed that the adoption of GSCM in developing countries remains in its early stages and that GSCM barriers remain under researched in new contexts (Tseng et al., 2019). According to Wooi and Zailani (2010) and Abdullah et al. (2016), resource barriers are the key obstacles to the implementation of green supply chain initiatives in Malaysia's manufacturing industry. Mathiyazhagan et al. (2013) developed the ISM model with 26 barriers based on a literature review and discussion with experts to identify the most dominant barrier to implementing GSCM in Indian auto component manufacturing industries. Their results revealed that the dominant barrier to GSCM implementation is maintaining environmental awareness among suppliers. Earlier studies (e.g., Mudgal et al. (2010); Sunil Luthra et al. (2011) presented similar findings. Mudgal et al. (2010) conducted a study on barriers to green supply chain practices in Indian manufacturing industries. A lack of corporate social responsibility, top management commitment and support from the government were found to be the most important barriers hampering the implementation of GSCM. Sunil Luthra et al. (2011) identified various other barriers to GSCM implementation in the Indian automobile industry. The lack of supportive government policies was identified as the most important barrier to GSCM, followed by a lack of commitment from top management.

Mehrabi et al. (2012) used the ANP to identify the influential barriers to implementing GSCM in the petrochemical industries in Iran, and the results indicated that the lack of understanding among supply chain stakeholders was the most important barrier. Additionally, Al Zaabi et al. (2013) conducted a study in the fastener manufacturing industry in India. The complex design to reduce the consumption of resources and energy, the cost of environmentally friendly packaging and lack of clarity regarding sustainability were the dominant barriers to implementing sustainable supply chain management (SSCM). M. A. Moktadir et al. (2018) studied the barriers to the implementation of SSCM in the Bangladeshi leather industry. Local customers' lack of awareness of green products and the lack of top management commitment were determined to be the most significant barriers to SSCM.

Q. Zhu and Geng (2013) conducted research initiated by the Chinese government to investigate drivers of and barriers to implementing energy saving and emission reduction (ESER) policies. The study showed that the implementation level of extended supply chain activities among Chinese manufacturers was very low, and the lack of financial gain, resources and capabilities was the primary barrier. Wang et al. (2016) investigated the key barriers to implementing GSCM from the food packaging industry's perspective in an Indian context by using the DEMATEL method. Their study revealed that Indian packaging industries have received inadequate training regarding the green concept. Mathiyazhagan et al. (2016) identified 38 barriers from the literature to analyze the implementation of GSCM in the plastic processing industry in India. These authors identified a lack of technology to adopt GSCM and inefficient disposal technology to be the main barriers. Further, A. Majumdar and Sinha (2018) identified 36 barriers related to GSCM practices in the Indian clothing sector, of which the complexity of the green process and system design was the most important barrier. Similarly, Abhijit Majumdar and Sinha (2019) sought to analyze the main barriers to green textiles in Southeast Asian countries. Their findings were the same, thereby confirming that the complexity of the green process and system design is the main obstacle to GSCM implementation in the textile industry.

The lack of awareness among Malaysian manufacturers of green innovation barriers drove Abdullah et al. (2016) to investigate the internal and external factors that hinder green innovation initiatives. The authors found that manufacturing firms and policymakers should direct their attention towards environmental resource issues and attitudinal and perception barriers.

Movahedipour et al. (2017) offered a systematic literature review that identified the most influential barriers to implementing SSCM in Iranian electrical power supply manufacturing industries. Inadequate information and 
technological implementation have been identified as key high-impact barriers. In a separate study, undertaking similar research on the Indian power industry, Soda et al. (2017) recommended that industries should clearly identify their barriers and determine their weak areas to improve the effectiveness of their GSCM practices. They developed ISM methodology in their research on 16 barriers to measure the strength of their driving powers and their mutual dependency. The lack of government support and limited investment in green measures were characterized as having high driving power.

Mathiyazhagan et al. (2016) analyzed the implementation of GSCM in the plastic processing industry in India. The authors identified the most dominant barriers using statistical analysis as the lack of technology for adopting GSCM and inefficient disposal technology.

Because of the increasing amount of waste, improper disposal methods and landfilling, industries, governments and consumers have begun to consider remanufactured products. Remanufacturing is an encouraging process because of its impact on the global economy and its strategic advantage for sustainability. Xia et al. (2015) conducted a study to analyze the internal barriers for remanufacturers in the Chinese automotive sector. The results of the study showed that the lack of funds for research in new technologies was a significant obstacle in the implementation of remanufacturing. In the Indian context, Govindan et al. (2016) investigated the barriers to auto parts remanufacturing, and two methodologies were used to evaluate the barriers, ISM and fuzzy integrated ANP. The study found that the cost of implementation and customer acceptance are the most influential barriers in auto parts remanufacturing.

\subsection{Potential Tensions}

Approaching the supply chain through green activities is a clear indication of the increasing attention being given to society and the environment (Ivascu et al., 2015). The integration of sustainability into supply chain management starts by focusing on combining environmental activities with supply chain management practices (Ahi \& Searcy, 2013). This section explores the types of tensions that are related to sustainability, with particular emphasis on tensions associated with environmental activities. Sustainability includes several contradictory yet interrelated elements, and it is associated with multiple tensions as firms are required to balance their economic, social and environmental objectives (Van der Byl \& Slawinski, 2015). Sustainability tensions may arise when at least two of the three pillars of sustainability (social, economic and environmental) are conflicting. For instance, an increase in one causes the decrease of another (Daddi et al., 2019). The triple bottom line only identifies and demonstrates the three dimensions of sustainability; it does not systematically address the relationship among these aspects (Hahn et al., 2015). Therefore, sustainability is not an easy task because of tensions that might arise among economic, social, and environmental objectives (Hahn et al., 2015); between short-term profitability and long-term environmental objectives (Slawinski \& Bansal, 2015); and among the different interests of stakeholders (Hahn et al., 2015; Slawinski \& Bansal, 2015). According to Tura et al. (2019), "tensions are usually understood as negative consequences, such as strain and conflict, that result from contradictory goals and interests between collaborating actors, and can hamstring, aggravate or even break up business relationships and network partnerships". When companies work on optimizing their economic performance, tensions might arise regarding social and environmental performance (Van der Byl \& Slawinski, 2015). At the same time, prioritizing social and environmental gains over economic perspective can cause tensions. In short, tensions focus on contradictory pressures, goals or motivations with conflicting objectives and interests that can cause rifts in relationships or among network partners.

\subsubsection{Types of Tensions}

The following types of tensions have been explored in previous studies.

\subsubsection{Learning Tensions}

These tensions emanate from multiple time horizons in the process of "building upon and destroying the past to create the future" (Smith \& Lewis, 2011). According to Ozanne et al. (2016), learning tension "arises from processes of innovation and transformation that reveal tensions between old and new practices". GSCM practices require a long-term time frame, whereas firms often seek short-term objectives (e.g., next quarter's results). Thus, tensions may arise when organizational leaders need to set an action's deadline (e.g., long-term environmental objectives vs. short-term business goals). These tensions may occur as a result of change, adjustment processes or the creation of innovations.

\subsubsection{Belonging Tensions}

These tensions "exist between the individual and the collective, as individuals and groups seek both homogeneity and distinction" (Smith \& Lewis, 2011). At the company level, there are opposing yet coexisting roles and values that develop tension between personal and organizational interests (Smith \& Lewis, 2011; van Bommel, 2018). According to Ozanne et al. (2016), belonging tension "arises as organizational actors strive for both expression and group affiliation". The transition from TSCM to GSCM can create ambiguity among individuals, especially if the organizational mission is mainly about profit. In other words, some members of the firm are interested in environmental practices while others are more concerned about financial performance (van Bommel, 2018). 
Sustainability managers may get into trouble for reconciling their sustainability identity and their organizational identification (Ozanne et al., 2016). Hence, conflicts between individuals and the collective regarding identity and values highlight tensions of belonging, which stem from the unavoidable division of roles and tasks within the organization.

\subsubsection{Organising Tensions}

These tensions arise from complex systems that create competing designs, practices and processes to achieve the desired outcome (Smith \& Lewis, 2011). Similarly, Ozanne et al. (2016) stated that "tensions arising as complex organizational systems create competing designs, structures, processes, and practices to achieve the desired outcome". Tensions of this type include tensions between collaboration and competition-both tend to achieve a competitive advantage but may also impede each other (Brix-Asala et al., 2018). In the context of GSCM, organizing tensions arise when an environmental strategy is combined with the business requirements of a business model, triggering competition among organizational structures, activities and processes (van Bommel, 2018).

\subsubsection{Performing Tensions}

Performing tensions stem from "the plurality of stakeholders and their competing strategies and goals" (Smith \& Lewis, 2011) to satisfy the contradictory interests and demands of varied internal and external stakeholders. As Ozanne et al. (2016) explained, performing tension "arises from the need to satisfy multiple stakeholders in the organization's operations and results in competing strategies and goal". At the firm level, conflicting interests arise among internal stakeholders; because 'managers, employees, and the management all have different goals and priorities', it is difficult for a company to focus on one stakeholder without getting into problems with another (van Bommel, 2018). On the other hand, external stakeholders may have different demands, leading to tensions. For example, different NGOs have different demands that oppose one another and may be against shareholder interests. Another example is when the financial objectives of shareholders conflict with the environmental expectations of other stakeholders (Brix-Asala et al., 2018), making it difficult to satisfy all stakeholders. In short, performing tensions emanate from the multiplicity of both stakeholders and objectives.

\subsubsection{Temporal Tensions}

Temporal tensions describe short-term economic objectives clashing with long-term social and environmental goals (short-term decisions may not be aligned with long-term goals). These tensions usually arise because implementing GSCM requires a lengthy orientation (Hahn et al., 2015). For instance, environmental practices require long-term orientation and new advanced machinery, but firms may not be motivated to replace the old machinery because it is still working efficiently and generating profit.

\subsubsection{Spatial Tensions}

Spatial tensions refer to tensions that relate to intragenerational equity. Spatial equity refers to the equality of localization in space, primarily equitable opportunities for developed and developing regions, such as decisions regarding the localizing of pollution sites. For example, multinational organizations operate facilities in both developed and developing countries, which may lead to tensions because of different environmental or social standards and lead to questions regarding whether to adhere to international criteria, host country standards or the home country's standards (Hahn et al., 2015).

\subsubsection{Change Tensions}

The transition from TSCM to GSCM is usually accompanied by tensions related to the organizational change process, which could be related to technology, structural change and innovation. Change tensions can occur inside the organization and may be related to the types of innovations and tensions related to different pathways of technological and structural change. Change tensions may also occur as a result of external pressures (e.g., government or NGOs) to comply with societal and sectorial norms to maintain legitimacy (Hahn et al., 2015).

\subsubsection{Economic Tensions}

Economic tensions refer to "expectations or demands from one actor for other actors to invest or expend costs into technologies, processes, or new practices” (Tura et al., 2019). In the context of GSCM, economic tensions emanate primarily from higher investment, operating and opportunity costs. For example, economic tensions may arise when firms invest in new environmentally friendly technologies at the expense of postponing, freezing or even cancelling plans such as expanding and improving their current sales, service or production (Tura et al., 2019). Economic tensions usually exist because GSCM generates expensive operational changes; such costs could be for training, hiring new employees, obtaining different environmental certificates (e.g., ISO 14001) or developing an operational process to eliminate emissions and reduce waste. Sometimes green products are more expensive than traditional products. Therefore, firms that implement GSCM might face economic tensions with their customers.

\subsubsection{Structural Tensions}

Structural tensions relate to issues of network governance and point to the different ways interorganizational relationships are organized and governed within a network (Tóth et al., 2018; Tura et al., 2019). In the context of GSCM, structural tensions refer to an organization's need to increase monitoring and controlling requirements within the organization and its network. Some organizations depend on key suppliers who may dominate critical 
raw material; such a situation can make organizations concerned that implementing environmental practices may lead to increased dependency on those suppliers, who might leverage their unique positions to raise prices or influence contract position (Tura et al., 2019). The implementation of environmental practices influences several stakeholders across networks. Organizations need to manage each stakeholder's interests. However, because of conflicting interests and goals from different stakeholders within the network, organizations may be unable to balance the different interests for all network members. Therefore, structural tensions point to the need to manage and balance vertical and/or horizontal relationships with stakeholders (Tura et al., 2019).

\subsubsection{Psychological Tensions}

Psychological tensions refer to members' mental and emotional attitudes towards other members of the network and arise mostly from the uncertainty associated with sustainability practices (Pressey \& Vanharanta, 2016; Tura et al., 2019). These tensions "can be caused by mistrust as well as how actors are viewed by other actors in the network and their attitude towards one another" (Tóth et al., 2018). In the context of GSCM, psychological tensions stem primarily from increased technological, political and financial risks associated with implementing environmental practices. For instance, investing in sustainable technologies is associated with the uncertainty of return on investment, and many organizations face the risk of reducing short-term profitability for potential but uncertain long-term benefits. Psychological tensions that stem from political risks can take the form of political decisions that influence business products and services, such as taxation policies for renewable energy and chemical regulations (Tura et al., 2019). Psychological tensions can also arise between the organizations and their suppliers. Suppliers might need to access an organization's system to coordinate some green practices, but they organization may be reluctant to share because of the fear of revealing critical information or data regarding their processes and operations.

\subsubsection{Behavioral Tensions}

Behavioral tensions refer to the way that actors operate in operational or communicative practices within a business network. They indicate an actor's activities, routines and communicative practices and could be related to active and passive or cooperative and competitive behavior (Fang et al., 2011; Tóth et al., 2018; Tura et al., 2019). Behavioral tensions also stem from personal likes and dislikes, such as who will collaborate with whom or who wants to avoid joint work with a network member (Fang et al., 2011; Tóth et al., 2018). For organizations that implement GSCM, behavioral tensions may manifest primarily as increased disclosure requirements because organizations need to report on different environmental criteria to different stakeholders, such as environmental and political authorities, potential customers and network partners (Tura et al., 2019). According to Tura et al. (2019), increased workload, bureaucracy, training and social pressures can cause internal resistance to implementing sustainability practices within the organization; thus, tensions arise. The authors observed that behavioral tensions can arise in the form of lack of commitment, negative attitudes towards misunderstanding and purposely ignoring responsibility. Behavioral tensions may also arise between members of the entire supply chain because of the various objectives and interests of different network actors (Tura et al., 2019).

\subsection{Research gap and research contributions}

It is obvious from the literature that researchers are interested in analyzing barriers that might hinder GSCM implementation. Studies related to GSCM have been prominent in developed countries (Uddin et al., 2019). Implementing green practices in the industrial sector of some developed countries is compulsory because of pressure from society and the government (Song \& Gao, 2018; Troisi, 2015). Accordingly, environmental practices are widely utilized in the manufacturing industries of developed countries (Heydari et al., 2020). However, there are few studies from developing countries, which is a clear indicator that developing nations continue to pay less attention to green practices and still struggle with obstacles that hinder environmental activities. Studies have determined that different industries have different opinions regarding the execution of GSCM. Moreover, different countries have different opinions regarding barriers that impede GSCM implementation because countries have different environmental laws and policies (Bouzon et al., 2016; Govindan et al., 2014). From the previous sections, this study features the following research gaps:

Section 2.2 highlights that GSCM barriers have only been addressed in a few kinds of manufacturing industries. No research has been focused on identifying impediments to green practices in the food and beverage manufacturing sector in a developing country.

Section 2.3 points out that implementing a new strategy can be complicated. It highlights the research gap on tensions around GSCM adoption.

The contributions of this work are manifold and include (a) identifying barriers to GSCM implementation by a detailed literature review in the context of developing country manufacturing sectors and identifying the types of tensions that are related to sustainability, with particular emphasis on tensions associated with environmental activities; (b) investigating how GSCM barriers can create tensions among various stakeholders and (c) providing new insight and potentially a breakthrough for future studies into the barriers and tensions that could delay or prevent the adoption of green business activities. Therefore, this study contributes to the scant literature on the 
barriers of implementing GSCM in the food and beverage manufacturing sector and contributes to the GSCM literature by illustrating how the implementation of green practices can lead to tensions that may hinder the implementation of any new strategy.

\section{Problem description}

GSCM has emerged as an important trend among all manufacturing sectors, including food and beverage industries. The food and beverage manufacturing sector is significant in terms of promoting pollution-free products and reducing environmental impacts (Wang et al., 2016). As the FBI consumes a lot of resources that have a noticeable environmental impact, it's now facing two primary challenges: environmental and economic sustainability (Grekova et al., 2014). The food and beverage sector is very dynamic, undergoing permanent changes with respect to consumer demands (Ghadge et al., 2017). For instance, due to an increase in customers' environmental awareness and strict environmental regulations imposed by governments, the FBI is facing pressure to reduce its environmental impacts. At the same time, the majority of consumers' mainly ask for products that are affordable. Thus, this industry is facing challenges with respect to increasing its environmental practices in its operations without compromising the prices of its products (Grekova et al., 2014).

The motivation of this paper comes from the fact that it is dealing with an important topic, especially in the context of the Egyptian market, regarding obstacles to implementing GSCM activities in the FBI. According to the Egyptian Chamber of Food Industries, the FBI is the largest industrial sector with a high environmental impact (http://www.fei.org.eg/). Egypt exports over \$ 2.8 billion in food and beverage mainly to the Middle East. However, now, governments are imposing environmental regulations to encourage green procurement. This means that implementing GSCM is highly required for export industries, and this will have a high influence on the Egyptian industry. For this reason, the Egyptian FBI is being pressurized to implement GSCM in their practices. Therefore, the Egyptian FBI needs to adopt a proactive approach to address issues of green practices for future competitiveness

In Egypt, GSCM is still in its early stages, and the literature shows that only a few studies have been conducted to analyze and identify critical barriers that hinder GSCM implementation in the context of Egypt. This explains the gap in the literature regarding the implementation of a green supply chain in Egypt. It's not an easy task to eliminate all the barriers at once; thus, industries are required to identify and prioritize the key factors that can improve their environmental performance (Ghadge et al., 2017).

This research targeted three multinational companies that are leaders in the FBI around the world. These companies have already implemented environmental practices in developed countries and, thus, possess the knowledge and experience to implement GSCM. This research, however, will investigate the types of barriers that hinder these multinational companies from adopting green initiatives in the context of Egypt. Through detailed literature and discussion with experts, 39 barriers and 11 types of tensions have been identified. Barriers with definitions are presented in table 2 .

\subsection{Egyptian food and beverage manufacturing sector}

In the context of the MENA region, Egypt is the most populated country, with more than 100 million people. Due to this rapid population growth, the demand for food and beverage in this country continues to rise. According to the Arab-African Conferences and Exhibition, the Egyptian FBI is growing at a rate of 25\% annually, making Egypt an attractive market for foreign companies in this sector (www.foodafrica-expo.com). Furthermore, according to the Egyptian Chamber of Food Industries, more than 7000 factories are operating in this country, which generated \$23 billion in sales in 2018 (www.foodafrica-expo.com). International companies account over $\$ 8$ billion of these sales. The Egyptian food and beverages' sector has been home to many multinational companies, such as Kraft Heinz, PepsiCo, Nestle, Danone, and Coca-Cola, for many years. Thus, these leading multinational food and beverages' companies are actively present in the Egyptian market. Nestle, Kraft Heinz, and PepsiCo are the giants in the FBI across the world, and among their most important priorities are sustainable growth and reducing environmental impacts. These big companies have already implemented GSCM in developed countries; however, they are struggling to adopt environmentally sustainable practices in a developing country such as Egypt due to various barriers. Therefore, this study chose to examine Nestle, PepsiCo, and Kraft Heinz to identify the most critical barriers that hinder the implementation of GSCM.

\section{Solution Methodology}

This section presents the research method and the mode of data collection that were adopted by this study to identify the barriers that hinder GSCM implementation in the Egyptian FBI. Previous studies on the barriers to GSCM implementation were diversified in terms of methodology, as these studies were different in nature with different research questions. As stated above, our main goal was to review the literature and identify barriers and tensions that impede companies and industries from adopting environmental practices. Based on our literature review and discussions with experts, the most common barriers to GSCM accepted by the Egyptian food and 
beverage companies were identified. These identified common barriers were then analyzed using the AHP.

For the purpose of this study, interviews, questionnaires, and the decision group method were chosen to ask companies about the most important GSCM barriers. The decision group method was used to identify the common barriers for the selected companies and validate the categorizations of these barriers. In addition, the decision group method facilitates data collection to conduct a pairwise comparison. On the other hand, the questionnaire method was used because it facilitates easy collection of data (e.g., e-mails).

\subsection{Data collection}

This study targeted three large food and beverage multinational companies in Egypt. We chose these multinational companies based on direct visits. The process started by contacting the companies via a phone call to arrange a meeting. The process of data collection consisted of three phases. For the primary source of data, a qualitative method was utilized for interviews, followed by a questionnaire survey. Furthermore, a decision group was formed to collect and validate the data.

\subsubsection{The companies}

Nestle is a Swiss multinational food and drink company. It is one of the largest food company in the world, measured by revenues and other metrics. In 2018, the company ranked at the top of the list among food and beverage companies based on annual sales. Nestlé has over 8000 brands with a wide range of products, including baby food, bottled water, coffee, health care nutrition, and milkshakes and other beverages. Nestle defines sustainable development as "the process of increasing the world's access to higher quality food while contributing to long term social and economic development and preserving the environment for future generations" (www.nestle.com). Nestle products have been presented in the Egyptian market since 1870, and the company operates two factories there - the first for producing dry foods and the second for producing bottled water. Nestle Egypt provides employment to more than 3500 people. In 2011, Nestle Egypt decided to green their supply chain. This process started by collaborating with the company's suppliers, providing them with technical training and offering financial assistance. However, due to many obstacles, the company is unable to implement efficient environmentally sustainable practices.

PepsiCo is an American multinational food and beverage corporation. In 2018, PepsiCo ranked as the second-best food and beverage company based on its annual sales of $\$ 63.5$ billion. The company distributes its products across more than 200 countries, and its brands include Pepsi, Lays snacks, Tropicana juice, Mountain Dew, and others. PepsiCo defines sustainability as "meeting the needs of the present while strengthening the ability of future generations to meet theirs". PepsiCo Egypt employs sustainability to help make a difference. PepsiCo Egypt's strategy is "Performance with Purpose", which means that the company's financial goals go hand-in-hand with sustainability objectives (www.pepsico.com). Although the company has begun implementing some GSCM practices such as green packaging, it is being pressurized by its headquarters to implement more practices and follow the whole sustainability agenda of the company.

Kraft Heinz is the third largest food and beverage company in North America and the fifth largest food and beverage company in the world (www.kraftheinzcompany.com). This company's brands include Kraft, Heinz, Philadelphia, Planters, and others. Kraft Heinz's vision is to be "The Best Food Company, Growing A Better World" by enhancing the quality of people's lives through sustainability, health and wellness, and social responsibility. Kraft Heinz Egypt aims to change their traditional supply chain activities into environmental activities by 2020 . The company wants to achieve green practices in its manufacturing facilities to reduce green gas emission, solid waste, and energy consumption. Therefore, Kraft Heinz is currently investigating the kind of barriers that may hinder their implementation of environmental practices.

Table 1. Characteristics of the companies

\begin{tabular}{lccc}
\hline Characteristics & Nestle & Kraft Heinz & PepsiCo \\
\hline Sector & Food and Beverage & Food and Beverage & Food and Beverage \\
Size & Large & Large & Large \\
Country of Origin & Switzerland & USA & USA \\
Number of direct employees & More than 500 & More than 500 & More than 500 \\
Sectors interviewed & Environment & Engineering & Production \\
\hline
\end{tabular}

\subsubsection{Phase 1: Semi-structured interview}

For the collection of data, the semi-structured interview technique was chosen because it is known as the most appropriate method for collecting data in qualitative research (Bryman, 2003). The study began by conducting face-to-face interviews with managers who are responsible for sustainability issues in their companies. During this step, the primary purpose was to identify barriers that hinder or delay their companies in implementing GSCM. Before conducting these interviews, the goal of this study along with the concepts of GSCM were explained to the participants through properly prepared documents. In addition, the researchers explained the potential benefits and the usefulness of this study to each firm. Subsequently, the conversation proceeded using the prepared questions.

\subsubsection{Phase 2: Developing the questionnaire}


After reviewing the literature and interviewing the experts, a detailed questionnaire was constructed to facilitate the collection of data to identify the factors constraining GSCM practices. The survey questions were given to the participants during the face-to-face interview and were also sent to them via email. From the 39 identified barriers, the participants were requested to select the essential barriers to GSCM implementation by choosing "Yes" or "No" for each barrier. The participants were then asked to provide their feedback or comments in English.

4.1.4 Phase 3: Qualitative decision groups

in the final process of data collection, a decision group consisting of four experts was formed. These experts included the Chief Executive Officer (Kraft Heinz), Engineering manager (Kraft Heinz), Plant Manager (PepsiCo), and Market Engineering \& HSE Manager (Nestle). The main aim of forming a decision group was to identify the common barriers, validate the categorizations, and construct pairwise comparisons.

\subsubsection{Finalization of the common important barriers to GSCM implementation}

A total of 39 barriers to the implementation of GSCM were identified through the literature. To validate the collected barriers, the experts were requested to add or delete any barrier that hindered or delayed their company in implementing GSCM practices. Firstly, the managers exchanged views, and each provided their feedbacks independently. Secondly, the experts held a collective discussion, and their responses were collected. It was found that the experts accepted all the identified barriers, and a total of 18 barriers were selected as common.

\subsubsection{Categorizations of barriers in terms of relevant tensions}

Eleven types of tensions arising from the implementation of GSCM were identified from the literature. The experts were then asked to validate the selected barriers in terms of tension-type (see Table 3 ). In addition, they were requested to add a description for each barrier and an example to illustrate the tensions that may arise between various collaborating actors (see Table 4). This step required several discussions with the experts, as some types of tensions seem to have the same characteristics. Accordingly, the identified barriers were categorized under five types of tensions. The experts confirmed their agreement with the categorization of the barriers in terms of types of tensions. Lastly, the responses from the experts were gathered, and data was collected to be evaluated using the AHP approach.

Table 2 GSCM related barriers

\begin{tabular}{cll}
\hline Barriers & \multicolumn{1}{c}{ Description } \\
\hline 1. & $\begin{array}{l}\text { Inflation and currency } \\
\text { exchange rates }\end{array}$ & $\begin{array}{l}\text { Financial concerns would be affected by variations in } \\
\text { currency exchange rates and inflation. }\end{array}$ \\
2. & $\begin{array}{l}\text { Poor quality and lack of } \\
\text { skilled human resources in } \\
\text { adopting GSCM }\end{array}$ & $\begin{array}{l}\text { Quality human resources can support companies } \\
\text { with new ideas, adopt easily to new } \\
\text { systems/technology, use of different techniques to } \\
\text { solve problems. }\end{array}$ \\
3. $\begin{array}{l}\text { Changing regulations due } \\
\text { to phanging } \\
\text { climate }\end{array}$ & $\begin{array}{l}\text { Companies fear that permanently changing law, } \\
\text { legislation, and political decisions will affect their } \\
\text { environmental objectives. } \\
\text { To implement various green practices, such as green } \\
\text { purchasing, green manufacturing, and green design, }\end{array}$ \\
4. Cost implications & a substantial initial investment is required.
\end{tabular}

5. Lack of awareness about Industries face lack of awareness about reverse reverse logistics adoption logistics practice.

6. Lack of implementation in terms of environmental practices

7. Unwillingness to exchange information among supply chain partners

8. Restrictive company policies toward product/ process stewardship

9. International crisis and economic downturn

10. Supplier resistance to change towards environmental practices
This refers to a lack in terms of considering practices such as hazardous solid waste disposal, energy conservation, reusing and recycling materials, etc. Complexity in exchanging and sharing information among supply chain member is a critical barrier to GSCM implementation.

Product stewardship is the management code for assuring the safe handling and use of products over their entire life cycle.

Recession could affect the decision of implementing the green concept

Supplier's resistance to change towards environmental practices stems from the high costs of operational changes.

Reference

\section{Experts}

Sunil Luthra et al. (2011), Mathiyazhagan et al. (2013), Kamalakanta Muduli et al. (2013), Govindan et al. (2014) Movahedipour et al. (2017), M. A. Moktadir et al. (2018), Bouzon et al. (2018)

Kamalakanta Muduli et al. (2013), Jasneet Kaur et al. (2018)

Mudgal et al. (2010), Sunil Luthra et al. (2011), Walker and Jones (2012) Mudgal et al. (2010), Mathiyazhagan et al. (2013), Govindan et al. (2014), Jayant and Azhar (2014), Balon et al. (2016), Wang et al. (2016), J. Kaur and Awasthi (2018), Sirisawat and Kiatcharoenpol (2018), Abhijit Majumdar and Sinha (2019)

Sunil Luthra et al. (2011), Dube and Gawande (2016)

Agyemang et al. (2018)

Mudgal et al. (2010) Mathiyazhagan et al. (2013), Jasneet Kaur et al. (2018), M. A. Moktadir et al. (2018)

Sreejith Balasubramanian (2012), Balon et al. (2016)

Elbarkouky and Abdelazeem (2013), Walker and Jones (2012), Dhull and Narwal (2016) 
11. Lack of government willingness to invest

12. Lack of proper technology for recycling the generated waste

13. Conflicting priorities

14. Lack of new technology, material, and processes

15. Lack of ethical standard and corporate social responsibility

16. Lack of IT infrastructure systems like environmental monitoring system (EMS) in the organization

17. Disbelief about the environmental benefits

18. Lack of customer demands for green products

19. The high cost of hazardous waste disposal

20. Lack of community
pressure

21. Market competition and uncertainty

22. Lack of sustainable GSCM practices in the organization's vision and mission

23. Corruption because of poor legislation

24. Lack of infrastructure for suitability of waste management or disposal method

25. Lack of training and reward system for suppliers

26. Complexity to measure and monitor the environmental practice of suppliers
Industrial development is affected by the governments willingness to invest. For example, invest in the infrastructural to improve the industerial environment

Lack of advanced technology to perform recycling.

Conflicting priorities of various stakeholders can impede the adoption of GSCM.

This refers to the unavailability of appropriate advanced technology or process within an organization or in the market to implement GSC and the lack of environmentally friendly materials.

Absence of moral responsibility that includes a range of social and environmental growth.

Absence of an environmental monitoring system can hinder organizations from implementing effective environmental activities.

Organizations are not sure about the environmenta benefits in terms of market share, sales volume, and profit margin. Uncertainty of economic benefits among supply chain members impedes GSCM implementation.

Developing countries' consumers are not fully aware of green products, which may result in a lack of demand for them.

Disposing of hazardous waste is costly because of the threat involved.

Pressure from community such as NGOs can encourage organizations to seriously think to implement environmental practices to gain a good image and reputation.

Market competition and uncertainty are very high due to competitiveness and changing customers' requirements.

This refers to the lack of specific environmental goals in the company's mission and vision.

The presence of corruption affects new investment, new strategy, and discourage organizations from adopting green practices. Falsification of documents for audits and illegal payments to the local government or certification bodies.

Lack of advanced methodologies and modern equipment for waste management and disposal methods. Many industries, caring about getting rid of waste, rather than effectively disposing of it in an environmentally friendly way.

The absence of training and reward system to suppliers for implementing the green concept.

Companies struggle to measure the environmental performance of their suppliers because they do not have an effective monitoring/measuring system.
Govindan et al. (2014), Mathiyazhagan et al. (2017)

Sreejith Balasubramanian (2012), Elbarkouky and Abdelazeem (2013), Singh et al. (2016), Bouzon et al. (2016), Bouzon et al. (2018)

Walker \& Brammer (2009)

Govindan et al. (2014), Kamalakanta Muduli et al. (2013), A. Majumdar and Sinha (2018)

Mudgal et al. (2010), Sreejith

Balasubramanian (2012)

Mathiyazhagan et al. (2013),

Elbarkouky and Abdelazeem (2013), Govindan et al. (2014), Jayant and Azhar (2014), Balon et al. (2016), Dube and Gawande (2016), Movahedipour et al (2017), Mathiyazhagan et al. (2016), J. Kaur and Awasthi (2018)

Sreejith Balasubramanian (2012) Mehrabi et al. (2012), Abdulrahman et al. (2014), Singh et al. (2016)

Q. Zhu and Geng (2013) Mathiyazhagan et al. (2013), Wang et al. (2016), Nigam (2014), Mathiyazhagan et al. (2017) Abhijit Majumdar and Sinha (2019)

Mudgal et al. (2010), Sreejith Balasubramanian (2012), Balon et al. (2016)

Q. Zhu and Geng (2013), Al Zaabi et al. (2013), Govindan et al (2014), Wang et al. (2016) Sirisawat and Kiatcharoenpol (2018), Abhijit Majumdar and Sinha (2019)

Kamalakanta Muduli et al (2013), Barve and Muduli (2013)

Sunil Luthra et al. (2011), Jayant and Azhar (2014), Mehrabi et al. (2012)

Movahedipour et al. (2017), Sirisawat and Kiatcharoenpo (2018), Jasneet Kaur et al. (2018)

Kamalakanta Muduli et al. (2013), J. Kaur and Awasthi (2018)

Kamalakanta Muduli et al (2013), Soda et al. (2017), Mathiyazhagan et al. (2017)

Govindan et al. (2014), J. Kaur and Awasthi (2018), Abhijit Majumdar and Sinha (2019)

Govindan et al. (2014), Jayant and Azhar (2014), Oelze (2017) 
27. Lack of influence on subsuppliers

28. Lack of capabilities in R\&D on GSCM practice

29. Pressure for a lower price with competitors

30. Risk-averse attitudes

31. Lack of environmental legislation

32. Excessive bureaucracy

33. Cost of eco-friendly packaging

34. Perception that investment is not deemed necessary

35. Lack of an integrated information system

36. Reluctance and resistance to change among internal stakeholders

37. Uncertainty of economic benefits

38. Less access to market information

39. Shortage of green suppliers
The lack of influence on sub-suppliers is a key barrier during the implementation of GSCM practices. Most firms have undertaken supplier audit programs with only their first-tier suppliers. Extending the green behavior to the second and higher-tier suppliers is a challenging issue.

Lack of R\&D on GSCM practices is an importan reason for not moving towards environmental practices.

Organization finds it hard to keep the prices lower and implement GSCM jointly, as GSCM practices are very costly, e.g. Green purchasing, green manufacturing, green logistics, etc.

Risk-averse attitudes affect the implementation of the environmental practices and is considered as a barrier. Unwillingness to take a risk, e.g., Fearing product failure. Industries are not interested in taking the risk of implementing the green concept

Lack of government legislation concerning environmental protection.

Excessive bureaucracy may hinder or prevent the implementation of the green supply chain. Bureaucratic barriers include situations in which special permissions and rezoning are needed to develop GSCM infrastructure.

The high cost of environmental packaging could be a barrier to becoming green.

Investment is sometimes not perceived as being necessary, and this stops industries from adoption.

An efficient integrated information system is very much necessary for supporting GSCM activities during various stages of the product's life cycle.

This refers to the fear of failure associated with a hesitation to convert to a new system among top management members and employees towards implementing GSCM.

Implementing GSCM is associated with uncertainty related to the potential benefits that are realized in the long run.

Lack of obtaining information regarding market (internal or global) may hinder or delay the green practices.

Implementing environmental practices requires green materials to be provided by suppliers. Firms are reluctant to implement green practices if these materials are not available from the standard distribution network.
Rauer and Kaufmann (2015), Geng et al. (2017)

Q. Zhu and Geng (2013) Abdullah et al. (2016), Dhull and Narwal (2016), Shrivastava et al. (2017)

Dhull and Narwal (2016), M. A. Moktadir et al. (2018), Pumpinyo and Nitivattananon (2014)

Shibin et al. (2016), Mathiyazhagan et al. (2016), A. Sajjad et al. (2015)

Ghadge et al. (2017), M. A. Moktadir et al. (2018), Soda et al. (2017)

Aragão and Jabbour (2017), Geng et al. (2017)

Govindan et al. (2014), Da Silva et al. (2018)

Perotti et al. (2015)

Mudgal et al. (2010)

K. Muduli and Barve (2013), Sreejith Balasubramanian (2012)

Md Abdul Moktadir et al. (2018), Agyemang et al. (2018)

M. A. Moktadir et al. (2018)

S. Balasubramanian and Shukla (2017), Elbarkouky and Abdelazeem (2013), Agyemang et al. (2018)

Table 1 Categorization of the selected barriers based on their relevant type of tension

\begin{tabular}{|c|c|c|c|c|c|c|c|c|c|c|c|}
\hline \multicolumn{12}{|c|}{ Tensions } \\
\hline Common selected barriers & Organizing & Temporal & Spatial & Economic & Behavioural & Structural & Change & Psychological & Learning & Performing & Belonging \\
\hline $\begin{array}{l}\text { Lack of customer demands for } \\
\text { green products }\end{array}$ & & & & $\checkmark$ & & & & & & & \\
\hline $\begin{array}{l}\text { Complexity in measuring and } \\
\text { monitoring the environmental } \\
\text { practice of suppliers }\end{array}$ & & & & & & $\checkmark$ & & & & & \\
\hline Cost implications & & & & $\checkmark$ & & & & & & & \\
\hline $\begin{array}{l}\text { Lack of sustainable GSCM } \\
\text { practices in an organization's } \\
\text { vision and mission }\end{array}$ & & $\checkmark$ & & & & & & & & & \\
\hline Cost of eco-friendly packaging & & & & $\checkmark$ & & & & & & & \\
\hline $\begin{array}{l}\text { Uncertainty of economic } \\
\text { benefits }\end{array}$ & & & & & & & & $\checkmark$ & & & \\
\hline Shortage of green suppliers & & & & & & $\checkmark$ & & & & & \\
\hline $\begin{array}{l}\text { Lack of new technology, } \\
\text { material, and processes }\end{array}$ & & & & & & & $\checkmark$ & & & & \\
\hline $\begin{array}{l}\text { Inflation and currency } \\
\text { exchange rates }\end{array}$ & & & & $\checkmark$ & & & & & & & \\
\hline $\begin{array}{l}\text { Lack of an } \\
\text { information system }\end{array}$ & & & & & & $\checkmark$ & & & & & \\
\hline $\begin{array}{l}\text { Lack of implementation in } \\
\text { terms of environmental } \\
\text { practices }\end{array}$ & & & & & & & $\checkmark$ & & & & $\checkmark$ \\
\hline Conflicting priorities & & $\checkmark$ & & & & & & & & $\checkmark$ & \\
\hline $\begin{array}{l}\text { Unwillingness to exchange } \\
\text { information among } \\
\text { chain partners }\end{array}$ & & & & & & & & $\checkmark$ & & & \\
\hline $\begin{array}{l}\text { Perception that investment is } \\
\text { not deemed necessary }\end{array}$ & & $\checkmark$ & & & & & & & & & \\
\hline Market competition and & & & & & & & & $\checkmark$ & & & \\
\hline
\end{tabular}




\section{uncertainty}

Supplier resistance to change

towards environmental

practices

Changing regulations due to

changing political climate

Reluctance and resistance to

change among internal

stakeholders

Table 2 Barriers' descriptions in terms of tensions

\begin{tabular}{|c|c|c|c|c|}
\hline \multicolumn{5}{|c|}{ Experienced by and with } \\
\hline Barrier ca & ategory & Actor 1 & Actor 2 & Description \\
\hline \multicolumn{5}{|c|}{ Structural Tensions } \\
\hline 1. & $\begin{array}{l}\text { Complexity in measuring } \\
\text { and monitoring the } \\
\text { environmental practice of } \\
\text { suppliers }\end{array}$ & Organisation & Suppliers/Customers & $\begin{array}{l}\text { Organizations struggle to measure the } \\
\text { environmental performance of their suppliers } \\
\text { because they do not have an effective } \\
\text { monitoring/measuring system. }\end{array}$ \\
\hline 2. & Shortage of green suppliers & Organisation & Suppliers & $\begin{array}{l}\text { Due to the limited number of green suppliers, } \\
\text { companies may need to increase dependency on } \\
\text { key suppliers who have a dominant role in } \\
\text { supplying green material. Increasing dependence } \\
\text { on green suppliers can put companies at risk, } \\
\text { especially if those suppliers have opportunistic } \\
\text { behavior. }\end{array}$ \\
\hline 3. & $\begin{array}{l}\text { Lack of an integrated } \\
\text { information system }\end{array}$ & Organisation & Suppliers/Customers & $\begin{array}{l}\text { When supply chain partners do not share } \\
\text { information through an efficient integrated } \\
\text { system, they are not able to manage problems } \\
\text { effectively, leading to tensions. Structural tensions } \\
\text { usually arise between supply chain partners due to } \\
\text { the absence of an effective information system. }\end{array}$ \\
\hline \multicolumn{5}{|c|}{ Temporal tensions } \\
\hline \multicolumn{2}{|c|}{ 4. Conflicting priorities } & $\begin{array}{l}\text { Top } \\
\text { management }\end{array}$ & Top management & $\begin{array}{l}\text { Intertemporal choice causes decisions dilemmas, } \\
\text { in which short-term decisions may not align with } \\
\text { long-term goals. Temporal tensions may arise due } \\
\text { to conflicting objectives and varying interests of } \\
\text { internal stakeholders. }\end{array}$ \\
\hline 5. & 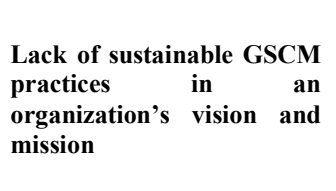 & Organisation & $\begin{array}{l}\text { Government/Society } \\
\text { /NGOs }\end{array}$ & $\begin{array}{l}\text { Tensions may arise if a company's mission and } \\
\text { vision neglect environmental practices and social } \\
\text { concerns. Temporal tensions may exist when an } \\
\text { organization's mission is related to financial } \\
\text { objectives, not their vision for environmental } \\
\text { practices and social concerns. }\end{array}$ \\
\hline 6. & $\begin{array}{l}\text { Perception that investment } \\
\text { is not deemed necessary' }\end{array}$ & Organisation & $\begin{array}{l}\text { Government/Society } \\
\text { /NGOs }\end{array}$ & $\begin{array}{l}\text { Environmental practices require long-term } \\
\text { orientation, but firms may not have the motivation } \\
\text { to invest, as it's deemed not necessary for the } \\
\text { meantime. }\end{array}$ \\
\hline \multicolumn{5}{|c|}{ Change tensions } \\
\hline 7. & $\begin{array}{l}\text { Lack of implementation in } \\
\text { terms of environmental } \\
\text { practices }\end{array}$ & Organisation & $\begin{array}{l}\text { Government/Society } \\
\text { /NGOs }\end{array}$ & $\begin{array}{l}\text { Tensions may arise between a firm's practices and } \\
\text { the need to comply with institutional pressure. } \\
\text { Firms face external pressures to change their } \\
\text { traditional practices to become more } \\
\text { environmentally friendly. }\end{array}$ \\
\hline 8. & $\begin{array}{l}\text { Reluctance and resistance } \\
\text { to change among internal } \\
\text { stakeholders }\end{array}$ & $\begin{array}{l}\text { Top } \\
\text { management }\end{array}$ & Employees & $\begin{array}{l}\text { Employees may show resistance to the adoption of } \\
\text { new advanced technology (resistance to change), } \\
\text { as they believe that an increase in mechanization } \\
\text { may lead to firing and reduction of employment } \\
\text { opportunities, leading to tensions between the top } \\
\text { management and the employees. }\end{array}$ \\
\hline 9. & $\begin{array}{l}\text { Lack of new technology, } \\
\text { materials, and processes }\end{array}$ & Organisation & Market & $\begin{array}{l}\text { Companies that are willing to change their } \\
\text { traditional practices to environmental practices } \\
\text { may suffer from the lack of advanced technology } \\
\text { or green materials, leading to tensions. }\end{array}$ \\
\hline \multicolumn{5}{|c|}{ Psychological tensions } \\
\hline 10. & $\begin{array}{l}\text { Uncertainty of economic } \\
\text { benefits }\end{array}$ & Suppliers & Organisation & $\begin{array}{l}\text { Companies will only implement environmental } \\
\text { practices if they are presented with the } \\
\text { opportunity to gain or earn financial or } \\
\text { operational benefits. The uncertainty of economic } \\
\text { benefits regarding green practices create tensions } \\
\text { within the company and among their supply chain } \\
\text { partners. }\end{array}$ \\
\hline
\end{tabular}



11. Market competition and Organisation Competitors/Customers
uncertainty

12. Unwillingness to exchange information among supply Suppliers Organisation chain members

13. Changing regulations due to changing political climate

Organisation Government/Regulatory bodies

Due to uncertainty and competition, it is tough for companies to offer lower prices and implement environmental practices at the same time. Suppliers might need to access a firm's system to coordinate some green practices, but organizations are often reluctant to share due to the fear of revealing critical information or data regarding their process and operations.

Organizations fear that permanently changing political decisions and legislation may negatively influence GSCM implementation.

\begin{tabular}{|crc|}
\hline Economic tensions & & \\
\hline 14. & $\begin{array}{l}\text { Supplier resistance to } \\
\text { change } \\
\text { environmental practices }\end{array}$ & \\
towards & Organisation Suppliers
\end{tabular}

15. Lack of customer demands for green products

Organisation Customers

Resistance to change among suppliers in the design process and technology affects the overall performance of the chain. A supplier's resistance to change towards environmental practices stems from the high costs of operational changes.

Sometimes, green products have higher prices compared to traditional products; therefore, firms may charge higher prices from the customer, and this might lead to economic tensions between the company and its customers.

Due to the higher investment required to implement environmental activities, economic

Organisation Organization's financial, Top production and sales management department

tensions may arise within the company between different departments. Economic tensions primarily emanate from higher investment requirement to implement green practices.

Economic tensions may arise between an organization and its customers who request environmental packaging, and it could also arise between the company and its suppliers, as companies force its suppliers to support them with green packaging. Suppliers might see such a change as requiring an expensive process.

The instability of the currency exchange rate and

18. Inflation and currency Organisation Government/Suppliers/ external pressures to implement green practices can lead to tensions between organizations and the government and market.

\subsection{An overview of the AHP methodology (analytic hierarchy process)}

This research utilized the AHP approach as a solution methodology to identify the essential barrier for GSCM adoption. The objective of this research is to rank the important barriers for GSCM implementation. The AHP is used to help decision-makers to prioritize the selected GSCM barriers. The AHP approach was first used by T. Saaty in the 1970s. Since its invention, it has been suggested as a tool to analyze complex problems based on arithmetic and mindset hierarchy, and it has been widely used by decision-makers and researchers. The analytic hierarchy process is a multiple criteria decision-making tool, and it is considered as a theory of measurement by constructing a pairwise comparison matrix based on the judgments of experts to set priority scales (T. L. Saaty, 2008). This approach compares criteria with respect to a criterion in the form of a pairwise mode (T. Saaty, 1980; T. L. Saaty, 2008). The popularity of AHP arises from its ease in terms of being integrated with different techniques such as Linear Programming, Quality Function Deployment, Fuzzy Logic, etc. (Vaidya \& Kumar, 2006). However, despite the ability of the AHP to solve complex decision problems, the approach has some limitations; for example, its judgmental scale is unbalanced (Sirisawat \& Kiatcharoenpol, 2018). The steps involved in the AHP approach have been listed as follows:

- Identifying barriers and types of tension from the literature

- Conducting interviews and collecting data

- Categorizing barriers in terms of tension-type

- Constructing a set of pairwise comparison based on expert judgment through a nine-point Saaty's scale

- Identifying normalized weights for each barrier category and each specific barrier

- Checking and evaluating the consistency of each pairwise comparison matrix by calculating relative weights and $\lambda$ Max for each

- Computing the consistency Index (CI) for each pairwise comparison matrix

$$
C I=\frac{\lambda \max -\mathrm{n}}{n-1}
$$

- Computing the consistency ratio $(\mathrm{CR})$ to guarantee the consistency of each pairwise comparison matrix 


$$
C R=\frac{C I}{R I n}
$$

- Ensuring the value of the $\mathrm{CR}$ is less than $0.1(\mathrm{CR}<0.1)$ to have a better level of consistency and revaluating the matrix if the value of $\mathrm{CR}>0.1$

- Taking decisions based on the normalized values if $\lambda \mathrm{Max}, \mathrm{CI}$, and CR are satisfactory

- Computing the global weight for each specific barrier and ranking them accordingly

4.2.1 Evaluation of the GSCM barriers to determine their relative importance using the AHP approach

The final list of common barriers was evaluated using the AHP, and their relative importance was determined through expert input. Using experts' input, a hierarchical structure consisting of five categories was constructed (see Fig. 1). The four levels of this structure have been explained as follows:

Level 1: This level presents the objective/overall goal.

Level 2: This level lists the five barrier categories.

Level 3: This level lists the 18 specific barriers.

Level 4: This level is concerned with identifying critical barriers.

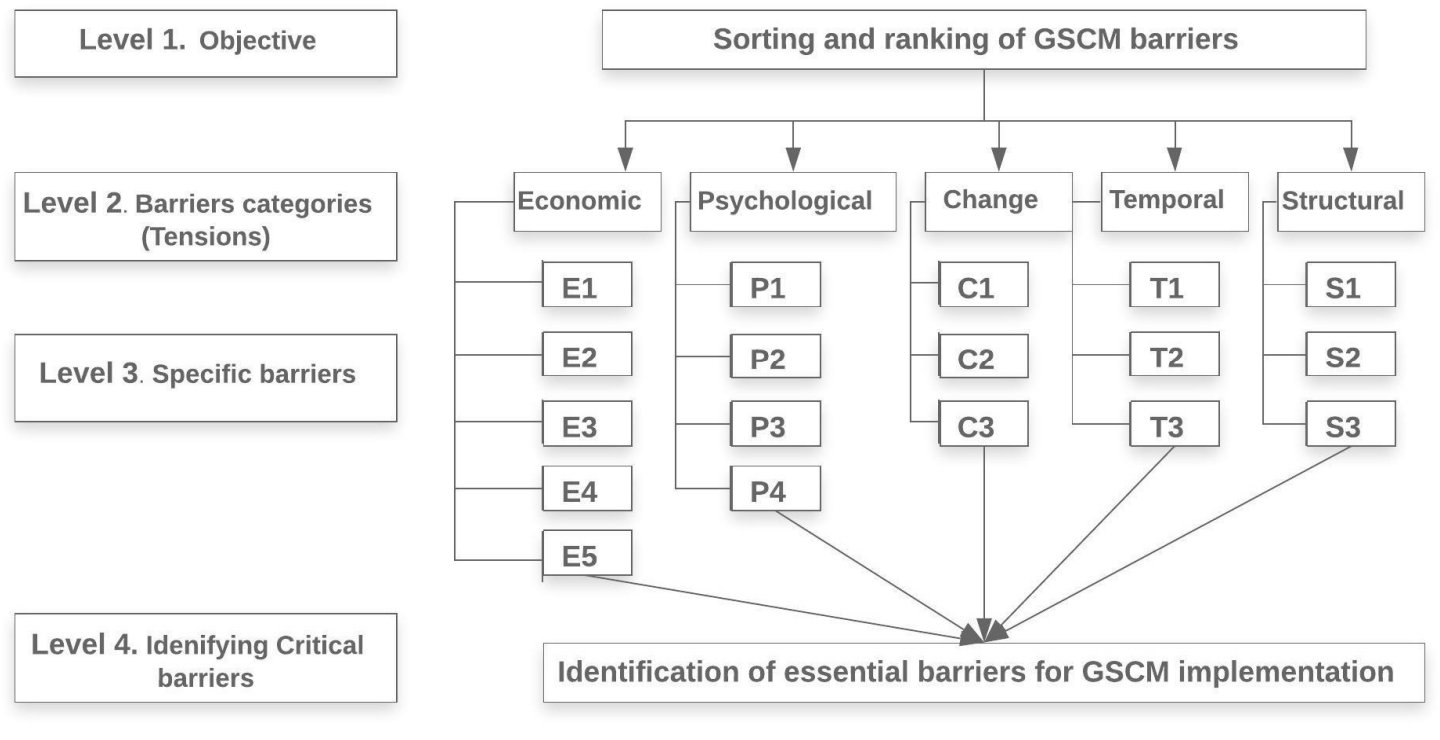

Figure 1 AHP Hierarchical Structure

The four experts were asked to identify the pair-wise comparison's weight using Saaty's scale values.

Table 3 Scales in pairwise comparison [adopted from (T. Saaty, 1980; T. L. Saaty, 2008)]

\begin{tabular}{|lll|}
\hline Intensity of importance & Definition & Explanation \\
\hline 1 & $\begin{array}{l}\text { Equal importance } \\
\text { Moderate importance }\end{array}$ & $\begin{array}{l}\text { Two activities equally contribute to the objective } \\
\text { Experience and judgement slightly favour one } \\
\text { activity over another }\end{array}$ \\
5 & $\begin{array}{l}\text { Strong importance } \\
\text { Experience and judgment strongly favour one } \\
\text { activity over another } \\
\text { An activity is favoured very strongly over } \\
\text { another } \\
\text { The evidence favouring one activity over another } \\
\text { is of the highest possible order affirmation } \\
\text { Used to represent a compromise between } \\
\text { preferences }\end{array}$ \\
\hline
\end{tabular}

The steps of this study have been presented through a flow chart, as can be seen in Fig. $\mathbf{2}$. 


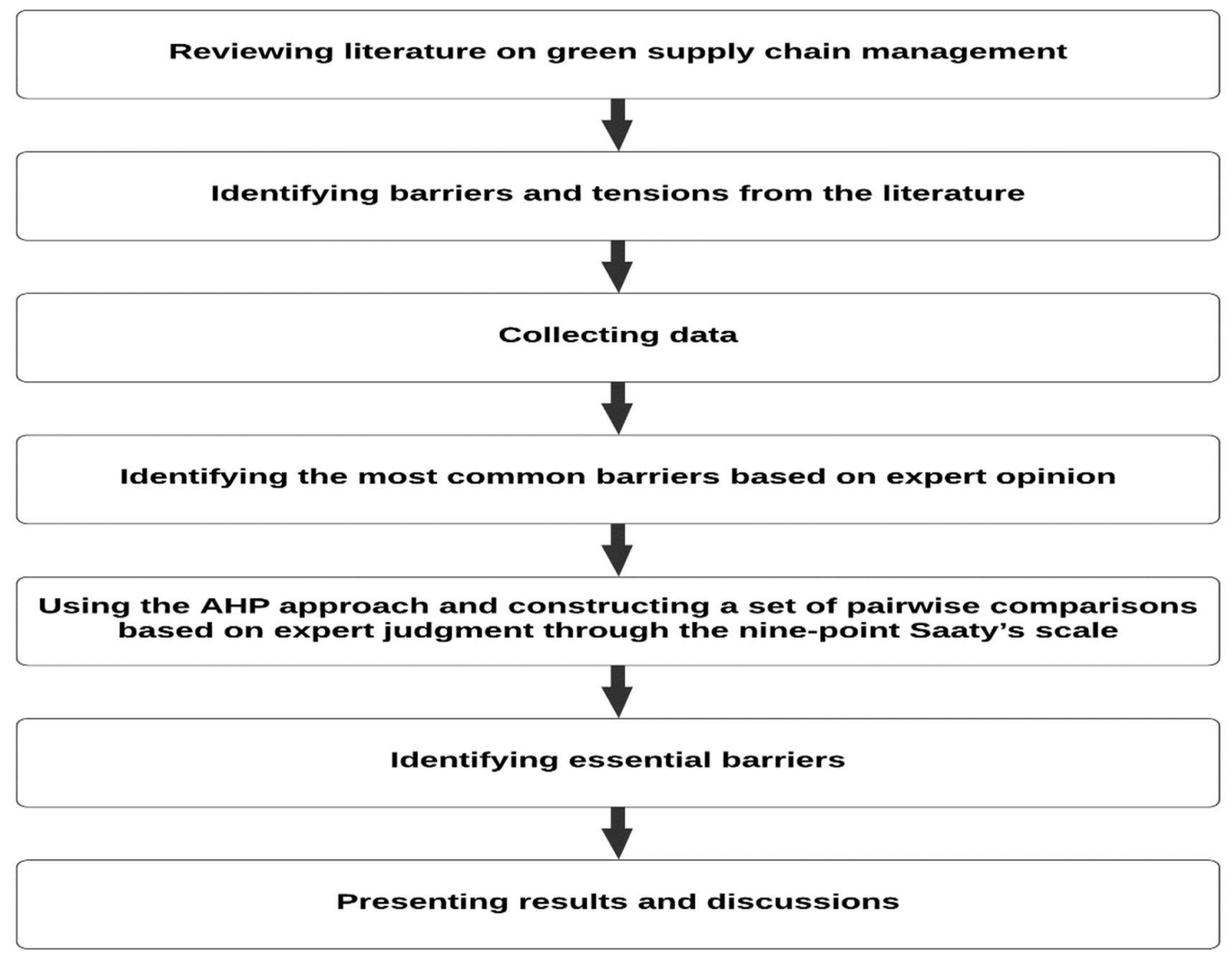

Figure 1. Flowchart of research

Table 6 Pairwise Comparison Matrix for Categories of GSCM Barriers

\begin{tabular}{lccccc}
\hline & $\begin{array}{l}\text { Economic } \\
\text { tensions }\end{array}$ & $\begin{array}{l}\text { Structural } \\
\text { tensions }\end{array}$ & $\begin{array}{l}\text { Temporal } \\
\text { tensions }\end{array}$ & $\begin{array}{l}\text { Change } \\
\text { tensions }\end{array}$ & $\begin{array}{l}\text { Psychological } \\
\text { tensions }\end{array}$ \\
\hline Economic tensions & 1 & 7 & 5 & 3 & 3 \\
Structural tensions & $\mathbf{0 . 1 4 2 8 5 7 1 4 3}$ & 1 & 0.2 & 0.142857143 & $\mathbf{0 . 3 3 3 3 3 3 3 3 3}$ \\
Temporal tensions & $\mathbf{0 . 2}$ & 5 & 1 & 0.2 & 1 \\
Change tensions & $\mathbf{0 . 3 3 3 3 3 3 3 3 3}$ & 7 & 5 & 1 & 1 \\
Psychological tensions & $\mathbf{0 . 3 3 3 3 3 3 3 3 3}$ & 3 & 1 & 1 & 1 \\
\hline
\end{tabular}

Table 7 AHP weights for barrier category

\begin{tabular}{lllc}
\hline Barrier category & Sorted weigh value & Percentage & Rank \\
\hline Economic tensions & $\mathbf{0 . 4 4 9 3 9 9 1 5 2}$ & $\mathbf{4 4 . 9 3 9 9 1 5 2}$ & 1 \\
Change tensions & $\mathbf{0 . 2 4 5 0 2 4 2 3 6}$ & $\mathbf{2 4 . 5 0 2 4 2 3 6 2}$ & 2 \\
Psychological tensions & $\mathbf{0 . 1 4 4 6 6 7 8 5 7}$ & $\mathbf{1 4 . 4 6 6 7 8 5 7}$ & 3 \\
Temporal tensions & $\mathbf{0 . 1 1 8 8 4 2 4 9 5}$ & $\mathbf{1 1 . 8 8 4 2 4 9 5 1}$ & 4 \\
Structural tensions & $\mathbf{0 . 0 4 2 0 6 6 2 6}$ & $\mathbf{4 . 2 0 6 6 2 5 9 5 5}$ & 5 \\
\hline
\end{tabular}

Maximum eigen value $=5.411199292 ;$ C.I. $=0.091785556$

5. Results and discussions

5.1 Barrier category ranking using the AHP

Table 6 presents the pairwise comparisons for the categories of GSCM barriers that were created based on the participants' expertise. From Table 7, we can observe that the related economic tensions are given the highest priority among the barrier's categories. Economic tensions may arise due to the demands of various stakeholders to invest or expend costs into new advanced clean technology, or further activities that would align with environmental practices (Tura et al., 2019). The tensions related to change receives the next highest weight. The transition from TSCM to GSCM is usually accompanied by tensions, which could be related to technology, 
structural change or innovation; for instance, this is applicable in situations where there is a conflict between a firm's practices and institutional pressures to comply with societal and sectorial norms to maintain organizational legitimacy (Hahn et al., 2015). The psychological tensions' category ranks third in terms of priority in the analysis. Psychological tensions primarily stem from increased technological, political, and financial risks associated with implementing environmental practices; for example, investing in sustainable technologies is associated with the uncertainty of return on investment. Mistrust between a company and its suppliers (mistrust arising from the fear of revealing critical information) are relevant issues in this category. Temporal tensions receive fourth place in our analysis. Temporal tensions arise from the fact that green practices require a more extended time orientation; this is applicable in situations of conflict between a firm's short-term objectives (e.g., next quarter's results) and longterm environmental goals (Hahn et al., 2015). Structural tensions rank fifth. Structural tensions arise due to the lack of monitoring and control techniques within a company and between a company and its suppliers (Tura et al., 2019).

\subsubsection{Barrier ranking for GSCM in Egyptian food and beverage industry}

Table 8 demonstrates the ranking of each barrier, which was determined based on the global weight values derived using the AHP methodology. The global weights for each barrier were calculated by multiplying the criteria weight of each barrier category with the local weights of each specific barrier. The result of each barrier in the global ranking based on barrier categories will be discussed in the following sections.

Table 8 Global ranking of GSCM barriers

\begin{tabular}{|c|c|c|c|c|c|}
\hline $\begin{array}{l}\text { Barrier } \\
\text { category }\end{array}$ & $\begin{array}{l}\text { Relative } \\
\text { weights }\end{array}$ & Specific barrier & $\begin{array}{l}\text { Relative } \\
\text { weights }\end{array}$ & $\begin{array}{l}\text { Global } \\
\text { weights }\end{array}$ & $\begin{array}{l}\text { Global } \\
\text { rank }\end{array}$ \\
\hline \multirow[t]{5}{*}{$\begin{array}{l}\text { Economic } \\
\text { tensions }\end{array}$} & 0.41149 & $\begin{array}{l}\text { Supplier resistance to change towards } \\
\text { environmental practices }(\mathrm{E} 1)\end{array}$ & 0.1050 & 0.0471 & 7 \\
\hline & & Lack of customer demands for green products (E2) & 0.0396 & 0.0178 & 13 \\
\hline & & Cost implications (E3) & 0.3829 & 0.1720 & 2 \\
\hline & & Cost of eco-friendly packaging (E4) & 0.0379 & 0.0170 & 14 \\
\hline & & Inflation and currency exchange rates (E5) & 0.4344 & 0.1952 & 1 \\
\hline \multirow{4}{*}{$\begin{array}{l}\text { Psychological } \\
\text { tensions }\end{array}$} & 0.14728 & Uncertainty of economic benefits (P1) & 0.0494 & 0.0071 & 18 \\
\hline & & Market competition and uncertainty (P2) & 0.2872 & 0.0415 & 9 \\
\hline & & $\begin{array}{l}\text { Unwillingness to exchange information among } \\
\text { supply chain members (P3) }\end{array}$ & 0.1054 & 0.0152 & 15 \\
\hline & & $\begin{array}{l}\text { Changing regulations due to changing political } \\
\text { climate }(\mathrm{P} 4)\end{array}$ & 0.5577 & 0.0806 & 4 \\
\hline \multirow[t]{3}{*}{$\begin{array}{l}\text { Change } \\
\text { tensions }\end{array}$} & 0.2693 & $\begin{array}{l}\text { Lack of implementing environmental practices } \\
\text { (C1) }\end{array}$ & 0.2289 & 0.0561 & 6 \\
\hline & & $\begin{array}{l}\text { Reluctance and resistance to change among } \\
\text { stakeholders (C2) }\end{array}$ & 0.6008 & 0.1417 & 3 \\
\hline & & $\begin{array}{l}\text { Lack of new technology, material, and processes } \\
\text { (C3) }\end{array}$ & 0.1701 & 0.0416 & 8 \\
\hline \multirow{3}{*}{$\begin{array}{l}\text { Temporal } \\
\text { tensions }\end{array}$} & 0.1398 & Conflicting priorities (T1) & 0.2518 & 0.0299 & 10 \\
\hline & & $\begin{array}{l}\text { Lack of sustainable GSCM practices in an } \\
\text { organization's vision and mission (no specific } \\
\text { environmental goal) (T2) }\end{array}$ & 0.5888 & 0.0699 & 5 \\
\hline & & Investment not perceived as necessary (T3) & 0.1592 & 0.0189 & 12 \\
\hline \multirow[t]{3}{*}{$\begin{array}{l}\text { Structural } \\
\text { tensions }\end{array}$} & 0.0588 & $\begin{array}{l}\text { Complex to measure and monitor the } \\
\text { environmental practice of suppliers (S1) }\end{array}$ & 0.3119 & 0.0131 & 16 \\
\hline & & Shortage of green suppliers (S2) & 0.1976 & 0.0083 & 17 \\
\hline & & Lack of integrated information system (S3) & 0.4904 & 0.0206 & 11 \\
\hline
\end{tabular}

5.1.2 Economic tensions

This category holds first place in the rankings shown above, and accordingly, it has the highest relative importance among the other categories. In this category, two barriers share the highest priority: inflation and currency exchange rate and cost implication.

In the economic tensions category, the barrier related to inflation and currency exchange rates (E5) ranks first in terms of criticality. According to experts, the inflation and currency exchange rates' barrier is the main driver 
of economic tension, as it is considered a game changer. For instance, the Egyptian pound has witnessed a rapid depreciation in the last ten years. Inflation rates have increased rapidly, and the country has undergone an exchange rate crisis (Helmy et al., 2018). Furthermore, Egypt has experienced unavailability of the US dollar at official prices, leading to the growth of black-market transaction. Thus, the Egyptian government decided to devalue the national currency. When devaluation took place, huge inflation occurred at the country level. Manufacturers who relied on imported materials needed to almost double their costs to keep their capital. Moreover, manufacturers cannot accommodate such a price increase, as it will put them out of the competition with local players, leading them to lose their market share. Accordingly, inflation and currency exchange rates have motivated economic tensions to arise between companies and their competitors, suppliers, and customers over increasing prices.

In GSCM implementation, cost implications (E3) are one of the most critical obstacles to environmental practices, more specifically GSCM, as indicated by its rank (second position). To implement various green practices such as green purchasing, green manufacturing, and green design, a substantial initial investment is required. Moreover, IT enablement, new clean technology adoption, hiring highly skilled employees, training the workforce to implement environmental practices also require a high initial investment (Sunil Luthra et al., 2011). Therefore, cost implication is a critical barrier to implementing green activities in the Egyptian FBI. According to expert opinion, the instability of the political and economic situations of Egypt led the country to prioritize this barrier. Furthermore, it should be noted that due to the higher investment required to implement environmental activities, economic tensions may arise within a company between different departments. For instance, the company's top management may need to invest in new green activities at the expense of postponing plans to improve or expand their current sales, service or production. Hence, tensions may arise between the company's top management and the sales or production department.

Supplier resistance to change towards environmental practices (E1) ranks third in terms of priority. To implement GSCM, companies request their suppliers to implement green practices. However, experts say that suppliers tend to resist changes in the design process and technology, which affects the overall performance of the chain. According to these experts, supplier's resistance to change towards environmental practices stems from the high costs of operational changes. This resistance, in turn, leads to economic tensions between the company and its suppliers, as companies want their suppliers to adapt their practices that fulfil environmental requirements.

A lack of customer demands for green products (E2) ranks fourth. In developing countries, consumers are not fully aware of green products, resulting in a lack of demand. Generally, there is a risk of customers voluntarily paying extra for green products, as companies may need to charge their customers higher prices due to cost increases in their operations, leading to economic tensions between a company and its customers.

The lowest priority in this category is given to the cost of eco-friendly packaging (E4). Various pollution hazards are arising due to the use of hazardous materials, making the environmental impact of packaging significant (Movahedipour et al., 2017). However, the high cost of environmental packaging could be a barrier to becoming green. Consequently, economic tensions may arise between a company and its customers and between the company and its suppliers as well. To illustrate, some customers pressurize companies to use environmental packaging, whereas other customers are not interested in green packaging or paying extra to obtain additional services. On the other hand, companies may pressurize their suppliers to provide them with eco-friendly packaging, but suppliers view such demands as requiring an expensive process.

\subsubsection{Change tensions}

To convert TSCM to GSCM, a change should occur - a change that includes renewing an organization's direction, structure, and capabilities. Organizations face pressures to change; these pressures arise from inside the organization itself and from their surrounding environment. This implies that organizations are continuously required to adjust to a changing environment to preserve their position in the market, indicating that changes are an inevitable part of the current market (Appelbaum et al., 2012). Thus, the change tensions' category acquires second position among other categories of barriers. This category comprises three barriers. Reluctance and resistance to change among internal stakeholders (C2) attain utmost importance in this category, as the primary obstacle in the implementation of GSCM is the lack of willingness to change (Balon et al., 2016). According to expert opinion, developing green products may not be welcomed in the Egyptian market, and this could lead to monetary losses and product failure. Accordingly, there is a fear of failure associated with a hesitation to convert to a new system among the members of top management to implement GSCM. Hence, tensions may arise among senior management members themselves. On the other hand, employees may resist the adoption of new advanced technology (resistance to change) due to the belief that an increase in mechanization may lead to firing and reduction of employment opportunities. This resistance, in turn, may lead to tensions between the top management and the employees.

The lack of implementation in terms of environmental practices (C1) barrier ranks second in terms of significance. Innovative environmental practices involve hazardous disposal, energy conservation, reusing, and recycling of materials (Sunil Luthra et al., 2011). However, due to the high initial investment, companies may prioritize saving costs over implementing environmental practices. However, firms face external pressures to 
change their traditional methods to become more environmentally friendly. Therefore, tensions may arise between a firm's practices and the need to comply with institutional pressure that can come from the government, society, NGOs, etc.

The lack of new technology, material, and processes (C3) comes last in the list. Experts view the nonavailability of advanced technology/processes within a company as a significant barrier towards implementing environmental practices. They agree that modern technology is not available in the market and that the only way to get it is by importing it from developed countries. Moreover, there is a lack of green material in the market, and if found, it can prove to be more expensive. Therefore, companies that intend to change their traditional activities to environmental practices may suffer from the unavailability of advanced technology or green material in the market.

\subsubsection{Psychological tensions}

In this category of four barriers, changing regulations due to changing political climate (P4) is the most critical. Since the Egyptian Revolution in 2011, the country has faced unstable political situations. According to experts, due to this instability in the political climate, multinational companies are not willing to take up new challenges and face high risks. Furthermore, these experts expressed their concerns regarding political decisions, especially those related to taxation policies and environmental regulations. Companies fear that permanently changing law, legislation, and political decisions will affect their environmental objectives. Thus, tensions may arise between companies and the government/regulatory bodies.

The market competition and uncertainty (P2) barrier ranks second in terms of criticality. According to experts, competition and uncertainty are very high in the Egyptian market, which can be attributed to changing customer requirements. Due to uncertainty and competition, it is difficult for companies to offer lower prices and implement environmental practices at the same time (Dhull \& Narwal, 2016). Accordingly, competition has a very critical role in the adoption and non-adoption of GSCM activities (Dhull \& Narwal, 2016). In other words, the uncertainty of market demand affects the successful implementation of GSCM (Balon et al., 2016). In short, due to the added uncertainty of market demand and competition, psychological tensions may arise between a company and its competitors. Tensions may also arise between a company and its customers, as the latter's requirements keep changing over time.

The unwillingness to exchange information among supply chain partners (P3) ranks third. Many studies have found that companies in supply chains that create strong relations in sharing information are more likely able to implement environmental practices than those that do not share information (Agyemang et al., 2018; Carter \& Rogers, 2008). One of the most important steps towards implementing GSCM is managing risks effectively. This can be achieved when all partners in a supply chain repeatedly address the issues they face and share information that creates trust among them and facilitates a collaborative relationship (A. Majumdar \& Sinha, 2018). Creating trust among supply chain partners is a motivating step towards implementing GSCM. Chiles and McMackin (1996) define trust as "the expectation that an exchange partner will not engage in opportunistic behavior, even in the face of countervailing short-term incentives". According to Sunil Luthra et al. (2013); A. Majumdar and Sinha (2018), trust in the supply chain is formed when a company involves itself with the downward-stream supply chain members (e.g., suppliers) to implement green activities and when upward-stream supply chain members (e.g., awareness level of customers) encourage environmental practices by purchasing green products. Developing a strong relationship with the suppliers' aids in creating trust and can reduce the inventory level, lower costs, improve the production process, etc. Obstacles such as confidentiality concerns or low level of trust stem from factors such as poor commitment on part of the suppliers, which can influence the implementation of GSCM. Furthermore, organizations and suppliers may not be willing to exchange environment-related information between each other due to confidentiality concerns, lack of trust, and the fear of giving others a competitive advantage (Govindan et al., 2014). Due to the lack of trust between companies and their suppliers, psychological tensions may arise between them. According to experts, suppliers may need to access the firm's system to coordinate some green practices, but organizations are often reluctant to share due to the fear of revealing critical information or data regarding their process and operations, leading to tensions between the company and its suppliers.

The uncertainty of economic benefits $(\mathrm{P} 1)$ received the lowest weight in this category, thereby ranking last among the 18 barriers. According to Bowen et al. (2001), companies will only implement environmental practices if they are given the opportunity to gain or earn financial or operational benefits. Implementing GSCM is associated with uncertainty related to potential benefits that are realized in the long run. Experts view the uncertainty of economic benefits regarding green practices as creating tensions within a company and among their supply chain partners. For instance, suppliers may perceive environmental activities to be costly and unnecessary, whereas companies demand their suppliers to follow their sustainability requirements. On the other hand, procurement managers may not realize the economic benefits of implementing GSCM, appearing to believe that taking a step towards becoming green is costly. This hypothesis that uncertainty of economic benefits of GSCM practices is an internal attitude and a perception barrier is validated by Govindan et al. (2014). This barrier, in turn, may create psychological tensions between a company and its suppliers or even within the company itself 
(procurement manager vs. senior managers).

\subsubsection{Temporal tensions}

The temporal tensions category holds fourth place among other categories. It comprises three barriers. Under this category, the lack of sustainable GSCM practices in an organization's vision and mission (T2) barrier holds the highest weight. A clear mission and vision strategy with an environmental focus drive companies to fight the eternal battle between commercialization and value (Movahedipour et al., 2017). According to experts, companies need to state environmental practices in their mission and vision, establish a department for environmental issues, provide employees with effective environmental training programs, choose suppliers based on environmental criteria, help to increase environmental awareness in society, support suppliers through environmental training programs, and motivate and reward their supply chain partners for adopting environmentally concepts, as tensions may arise if a company's mission and vision neglect environmental practices and social concerns. Thus, in turn, may lead to tensions between a company and customers/government/society/NGOs.

Next in rank is the barrier of conflicting priorities (T1). Environmental practices require long-term orientation and new advanced machines, but firms may not have the motivation to change the old ones, as they may still be working efficiently and generating profit. According to Laverty (1996), "the course of action that is best in the short term is not the same course of action that is best over the long run", clearly indicating that intertemporal choice causes decisions dilemmas, in which short-term decisions may not align with long-term goals. Sustainability tensions may arise when at least two of the three goals of sustainability (social, economic and environmental) conflict with each other; for instance, when one increases, another may worsen (decrease) (Daddi et al., 2019). Therefore, sustainability is a complex process due to tensions that may arise between economic, social, and environmental objectives (Hahn et al., 2015), between short-term profitability and long-term environmental objectives (Slawinski \& Bansal, 2015), and between the different interests of stakeholders (Hahn et al., 2015; Slawinski \& Bansal, 2015). According to expert opinion, tensions may arise when companies choose to focus on optimizing their economic performance instead of their social and environmental goals. According to Van der Byl and Slawinski (2015), trade-offs may arise when organizations prioritize financial perspective over social and environmental dimensions. This means that economic, social, and environmental dimensions cannot be focused on simultaneously. In short, temporal tensions may arise due to conflicting objectives and interests of various stakeholders.

Finally, the lowest priority is given to the barrier arising from the perception that investment is not deemed necessary (T3). According to experts, the majority of Egyptian customers have a low awareness of environmental products. Moreover, environmental practices need high initial investment and a long-term orientation, but companies do not have the motivation to invest, as it's deemed not necessary for the meantime. At the same time, multinational companies are pressurized by NGOs/society through media to adopt environmental initiatives as they do in developed countries. Thus, tensions arise between a company and its external stakeholders, as companies believe that investment is not perceived as necessary, whereas NGOs believe that multinational companies need to equally respect the customers of both developed and developing countries.

\subsubsection{Structural tensions}

The structural tension category ranks last being given the lowest weight. This category comprises three specific barriers. The barrier relating to the lack of an integrated information system (S3) ranks first in terms of criticality. For the time being, information and communication play a significant role in the development of companies and nations. In this context, previous studies on supply chain management found that information-enriched supply chains perform better (Mudgal et al., 2010). In this regard, implementing an efficient information system can guarantee information flow and exchange among supply chain partners (Agyemang et al., 2018). According to experts, an efficient integrated information system is preferably required to manage environmental activities. This is validated by Mudgal et al. (2010) who stated that an effective integrated system supports GSCM practices during various stages of the product's life cycle. Furthermore, experts stated that structural tensions usually arise between supply chain partners due to the absence of an effective information system. For instance, a fluctuation in demand (bullwhip effect) can cause tensions between an organization and its suppliers as well as between an organization and its customers. This is again validated by Mudgal et al. (2010) who stated that "information systems must be responsive to anticipate and accommodate operational change and customer demands". Therefore, when supply chain partners do not share information through an efficient integrated system, they are not be able to manage problems effectively, leading to tensions.

The barrier related to complexity in measuring and monitoring the environmental practice of suppliers (S1) comes next. It should be noted that the availability of appropriate environmental performance metrics is essential for developing new activities and justifying existing services (Mudgal et al., 2010). However, misalignment of metrics is seen as one of the main sources of inefficiency in supply chain interactions (Govindan et al., 2014; Mudgal et al., 2010). According to Govindan et al. (2014), monitoring/measuring suppliers' green performance is a complicated process. According to experts, their companies struggle to measure the environmental performance of their suppliers because they do not have an effective monitoring/measuring system. However, if an effective 
measuring/monitoring system was in place to evaluate suppliers' performance, it would improve their environmental practices, but to do that, they have to increase monitoring and controlling requirements for their suppliers. However, according to expert opinions, strengthening monitoring and controlling conditions between a company and its suppliers can lead to tensions. For instance, companies do not know whether their suppliers will adhere to their sustainability requirements regarding environmental practices or not, but if there is an effective monitoring and controlling system, companies will be able to know so, leading to tensions.

The barrier associated with the "shortage of green suppliers" (S2) received the lowest weight in this category. Previous studies have found that a limited number of green suppliers can be a barrier to implementing GSCM (Agyemang et al., 2018; Sreejith Balasubramanian, 2012). According to Elbarkouky and Abdelazeem (2013), Egypt suffers from a shortage of green suppliers. According to experts, not many suppliers in Egypt have a recognized international certificate to validate them as environmental suppliers, which is why there are a limited number of environmentally sustainable (green) suppliers. Due to this limited number, companies may need to increase their dependency on key suppliers who have a dominant role in supplying green material (Tura et al., 2019). However, experts state that increasing dependence on green suppliers can put them at risk, especially if those suppliers have opportunistic behavior that may increase their likelihood of increasing their prices or not respecting contract conditions. This is validated by Tura et al. (2019) who stated that depending on key suppliers can give away too much negotiating and pricing power. Hence, due to the limited number of green suppliers, tensions may arise between a company and its suppliers.

\section{Theoretical and Managerial implications 6.1 Theoretical Implications}

The findings of this paper offer two main contributions to the research community concerning obstacles that hinder GSCM, particularly in the manufacturing sectors of developing countries. First, previous literature has focused only on tensions in the context of sustainability - specifically the tensions between the sustainability of three dimensions (economic, social and environmental). This study investigated tensions around GSCM implementation by shedding light on the conflicts and negative consequences that may arise among various stakeholders and thus prevent the adoption of green practices. Our findings clarify how emerging tensions can lead to strain and conflict between actors, which can then affect the movement towards GSCM implementation. By investigating three large multinational companies (and the conflicts that may emerge in multi-actor contexts), we present a valuable empirical account of the potential tensions that can manifest when organizations intend to implement green practices.

Second, this study contributes to the literature on GSCM implementation. Previous studies have been limited in scope and focused only on barriers to GSCM adoption, on the basis that it is the only hurdle to embracing environmental practices. Our research demonstrates how tensions between collaborating actors can also act as obstacles to GSCM adoption. This study illustrates how GSCM barriers can lead to tensions, which indicates both tensions and barriers are impediments to GSCM implementation. Thus, organizations that seek to incorporate green practices in their supply chains must analyze GSCM barriers and investigate possible tensions.

\subsection{Managerial Implications}

Our research looked at the managerial perspective on the barriers and tensions that may arise because of GSCM implementation in the manufacturing industries. Our study has practical implications for managers in the manufacturing sector, particularly in the food and beverage industry. The results of this study will help managers better understand the challenges that can prevent their organizations from incorporating environmental practices in the TSCM. This study provides considerable guidance to the Egyptian food and beverage manufacturing industry in deciding to adopt green practices in its operations and supply chains. Manufacturing industries face multiple challenges when implementing GSCM; therefore, it is imperative for managers to identify these barriers and tensions. Identifying both barriers and tensions around GSCM implementation can encourage industrial leaders and decision makers by providing solutions for launching action plans to change TSCM to GSCM smoothly. Hence, industry leaders must identify the most significant barriers and tensions - identifying and assessing the impact of these obstacles on green practices could help industries prioritize the steps required to eliminate or mitigate these challenges. Furthermore, by understanding and identifying the tensions that may emerge because of GSCM implementation, managers may be able to create action plans to reduce or eliminate such tensions and conflicts and reduce the negative consequences among stakeholders. Because economic tension is ranked first among the barrier categories, managers should pay attention to the barriers that allow this type of tension to occur. Economic tensions primarily come from the higher investment required to realize green practices. The economic situation in Egypt has a major effect on the financial decisions managers face. This is especially true in terms of any new strategy that organizations implement. Our research shows a country's economic instability can affect the decisions surrounding GSCM implementation. In the economic tension category, the barrier concerning inflation and currency exchange rates ranks first in terms of criticality and is the main reason 
for the economic tension. This barrier was not identified as such in the literature review in the context of GSCM implementation. Managers should pressure the Egyptian government to set up rules regarding the currency exchange rates, and the government must provide foreign currencies to help companies import advanced technology that is essential for GSCM adoption. In addition, managers should urge the government to remove unnecessary and unclear laws that could delay the application of green practices. Our research will also encourage future researchers to discover strategies to deal with multiple tensions that may arise among stakeholders and impede the administration of GSCM practices.

\section{Conclusions, limitations and direction for future work}

In the last few years, the term green supply chain management (GSCM) has become popular and an area of interest for scholars. GSCM has been widely implemented by different industrial sectors to minimize the environmental impact of their supply chain activities, such as waste generation and pollution. Nowadays, industries are seeking to convert their TSCM to GSCM due to concerns about environmental sustainability and to improve their overall performance. However, despite the importance of GSCM, industries are reluctant to implement GSCM practices, as many barriers can arise while initiating GSCM in TSCM, which can lead to negative impacts. The presence of these barriers prevents or delays industries from implementing GSCM. It is, therefore, vital for industries to identify barriers that may hinder their environmental practices.

The objective of this study was determined after reviewing the literature to identify a gap within the field of this study. A gap was observed in terms of studies relating to implementing GSCM in the Middle East and Africa, especially in the context of Egypt. This implies that environmental practices in Egypt are still in its early stages. Hence, this paper aimed to investigate the barriers that hinder the implementation of GSCM in the Egyptian FBI. Additionally, it was observed that no study has examined GSCM barriers and the tensions that may arise between different stakeholders while implementing GSCM. Thus, this paper took a step ahead and categorized the identified barriers based on their appropriate type of tensions. This study was conducted across three multinational food and beverage companies in Egypt, and a qualitative approach was used to identify the common barriers and validate their categorizations. Our findings clarified how GSCM barriers may lead to tensions between various collaborating actors.

A total of 39 barriers and eleven types of tensions were identified after reviewing the literature. Out of the identified barrier, 18 common barriers were selected through interviews and the questionnaire survey. The selected common barriers were then categorized according to five types of tensions. Following this, the AHP was utilized to sort (rank and prioritize) these 18 barriers based on the judgments of four experts.

Based on the AHP's results, the category of "economic tensions" was found to have the most importance. This study shows that instability of the economic situation of countries can affect the implementation of GSCM. In the context of Egypt, its economic situation has not been stable since 2011, and because of this, companies have delayed the adoption of green practices, as it requires a substantial initial investment. This category comprises five barriers, namely, inflation and currency exchange rates, cost implications, supplier resistance to change towards environmental practices, lack of customer demands for green products, and the cost of eco-friendly packaging. It has been observed that these barriers can cause tensions within the company and between its partners. In this category, the main reason for tensions is the economic situation of the country, which prevents companies from taking up new environmental challenges.

The category of "change tensions" acquired second position among other categories of barriers in terms of significance. Due to an increase in customers, NGOs, and governments' environmental awareness, companies face pressure to change their TSCM activities into GSCM practices. This category comprises three barriers, namely, reluctance and resistance to change among internal stakeholders, lack of implementation in terms of environmental practices, and lack of new technology, materials, and processes. It has been observed that these barriers encourage tensions to arise between different stakeholders. For instance, implementing environmental practices requires new advanced technology and green materials, which are not available in the Egyptian market. Moreover, employees may show resistance to new challenges.

The category of "psychological tensions" ranks third. As mentioned before, Egypt faces unstable political situations, putting companies at high risks if they intend to take up new initiatives. This category consists of four specific barriers, namely, changing regulations due to changing political climate, unwillingness to exchange information among supply chain members, market competition, and uncertainty of economic benefits. It has been observed that psychological tensions are primarily caused by the added uncertainty associated with GSCM practices and the feeling of mistrust among supply chain partners. For example, the Egyptian market is full of uncertainty related to demand, policies, and regulations, and this can create tensions. Additionally, the fear of disclosing important information is inherent among all supply chain members, which creates mistrust among them, leading to tensions.

The category of "temporal tensions" ranks fourth. This category consists of three specific barriers, namely, lack of sustainable GSCM practices in an organization's vision and mission, conflicting priorities, and the 
perception that investment is not deemed necessary. Temporal tensions primarily arise from the fact that green practices require an extended time orientation; this is applicable in situations where there is a conflict between a firm's short-term objectives (e.g., next quarter's results) and long-term environmental goal.

The category of "structural tensions" ranks last. Compared to the economic tension category, the structural tension category is not important in the expert's point of view. This category comprises three specific barriers, namely, the lack of an integrated information system, complexity in measuring and monitoring the environmental practice of suppliers, and a shortage of green suppliers. It is clear that the structural tension category receives less weight in terms of significance than other barrier categories. Furthermore, the three specific barriers under this category are also given less weight compared to other barriers, implying that they can be eliminated easily.

While implementing GSCM practices, it is not possible to eliminate all the barriers simultaneously; therefore, companies must identify the barriers that pose major obstacles to environmental practices. For this purpose, this paper suggests a structural model to determine the barriers associated with the implementation of green practices in a supply chain.

As explained by the findings of this study, if a company adopts new green activities, it may generate tensions among its partners. It was found that tensions within a company stem from budgetary tensions between different departments as well as from employees' resistance to change; this resistance is associated with behavior. The tensions between companies and their suppliers are often related to the resistance of suppliers to meet new environmental criteria and the absence of information sharing through an efficient integrated system. The tensions between companies and customers mainly arise due to concerns related to increasing prices, the instability of economic and political situations, and the implementation of environmental practices (NGOs pressurize multinational companies to equally respect the environment of both developing and developed countries).

Our findings show that 17 barriers can cause tensions within organizations and between its partners. However, complexity in measuring and monitoring the environmental practices of suppliers produced a different result than other barriers. We found that the Egyptian FBI struggles to measure the environmental performance of their suppliers, as they do not have an effective monitoring/measuring system. It was also found that strengthening monitoring and controlling conditions between a company and its suppliers can lead to tensions. In other words, our results show that the presence of barriers is associated with rising tensions; however, while assessing another barrier, it was seen that eliminating barrier can also cause tensions.

Specific barriers (under each category) where are also sorted based on the AHP's global weights. This led to the finding that the inflation and exchange rate barrier is the most significant among the 18 barriers. Our results clearly demonstrate that companies face a lot of troubles due to inflation and the unstable exchange rate in Egypt and, thus, experts consider this barrier to be a dominant barrier to new challenges. Unpredictable economic situations associated with a lack of foreign currency is pressurizing multinational companies. For instance, NGOs and governments pressurize multinational companies to implement some environmental activities to encourage other local companies to take a step towards green practices. However, multinational companies' headquarters are skeptical about investing in new projects and prefer to wait for the Egyptian currency to become stable and for foreign currency to be available.

As it is difficult to remove all barriers simultaneously, industries must identify which barriers need to be taken care of in the initial stages of GSCM implementation. This work has identified important barriers that require to be eliminated in the context of the Egyptian FBI. The study found that the Egyptian FBI is still prioritizing the economic dimension over environmental and social concerns. In general, adopting environmental practices in Egypt is still in its early stages. Furthermore, this study categorized the identified barriers and ranked the barrier categories and specific barriers based on expert judgments by using the AHP approach.

This paper comes with some natural limitations. These limitations provide potential avenues for future research and empirical investigations. Firstly, the sample size was limited to only three large multinational food and beverage companies. Thus, it is highly recommended for future research to be conducted with a larger sample size, incorporating small and medium-sized companies. Additionally, future research should include different manufacturing sectors.

Secondly, interviews were conducted with only a single individual from each company. This prevents collecting different opinions from within the company. Thus, future research should be conducted with different individuals to obtain different views and produce a better analysis.

Thirdly, the AHP approach was used to prioritize barriers. However, the AHP has some disadvantages, such as vagueness, uncertainty, and bias. Thus, future research is encouraged to use fuzzy AHP to remove inherent vagueness and uncertainty (Luthra et al. 2011). The relationships between the barrier category and the identification of barriers can also be analyzed using other techniques, such as DEMATEL, ISM, and Grey DEMATEL technique.

Fourthly, the relationship between GSCM and its associated tensions need to be furthered analyzed to open the door for future researchers to investigate how barriers can cause tensions and why eliminating barriers can lead to tensions. 


\section{References}

Abdel-Baset, M., Chang, V., \& Gamal, A. (2019). Evaluation of the green supply chain management practices: A novel neutrosophic approach. Computers in Industry, 108, 210-20

Abdullah, M., Zailani, S., Iranmanesh, M., \& Jayaraman, K. (2016). Barriers to green innovation initiatives among manufacturers: The malaysian case. Review of Managerial Science, 10(4), 683-709 doi:10.1007/s11846-0150173-9

Abdulrahman, M. D., Gunasekaran, A., \& Subramanian, N. (2014). Critical barriers in implementing reverse logistics in the chinese manufacturing sectors. International Journal of Production Economics, 147, 460-71

Agyemang, M., Zhu, Q., Adzanyo, M., Antarciuc, E., \& Zhao, S. (2018). Evaluating barriers to green supply chain redesign and implementation of related practices in the west africa cashew industry. Resources, Conservation and Recycling, 136, 209-22 doi:10.1016/j.resconrec.2018.04.011

Ahi, P., \& Searcy, C. (2013). A comparative literature analysis of definitions for green and sustainable supply chain management. Journal of Cleaner Production, 52, 329-41 doi:https://doi.org/10.1016/j.jclepro.2013.02.018

Al Zaabi, S., Al Dhaheri, N., \& Diabat, A. (2013). Analysis of interaction between the barriers for the implementation of sustainable supply chain management. International Journal of Advanced Manufacturing Technology, 68(1-4), 895-905 doi:10.1007/s00170-013-4951-8

Ali, A., \& Bentley, Y. (2015). The impact of green supply chain management on performance: A study of garments industry in bangladesh. Paper presented at the International Conference on Sustainable Development (ICSD).

Ali, Y., Saad, T. B., Sabir, M., Muhammad, N., Salman, A., \& Zeb, K. (2020). Integration of green supply chain management practices in construction supply chain of cpec. Management of environmental quality, 31(1), 185-200 doi:10.1108/meq-12-2018-0211

Appelbaum, S. H., Habashy, S., Malo, J.-L., \& Shafiq, H. (2012). Back to the future: Revisiting kotter's 1996 change model. Journal of Management Development, 31(8), 764-82 doi:10.1108/02621711211253231

Aragão, C. G., \& Jabbour, C. J. C. (2017). Green training for sustainable procurement? Insights from the brazilian public sector. Industrial and Commercial Training, 49(1), 48-54 doi:10.1108/ICT-07-2016-0043

Balasubramanian, S. (2012). A hierarchiacal framework of barriers to green supply chain management in the construction sector.

Balasubramanian, S., \& Shukla, V. (2017). Green supply chain management: An empirical investigation on the construction sector. Supply Chain Management, 22(1), 58-81 doi:10.1108/SCM-07-2016-0227

Balon, V., Sharma, A. K., \& Barua, M. K. (2016). Assessment of barriers in green supply chain management using ism: A case study of the automobile industry in india. Global Business Review, 17(1), 116-35

Bansal, P., \& DesJardine, M. (2014). Business sustainability: It is about time. Strategic Organization, 12(1), 7078 doi:10.1177/1476127013520265

Barve, A., \& Muduli, K. (2013). Modelling the challenges of green supply chain management practices in indian mining industries. Journal of Manufacturing Technology Management, 24(8), 1102-22

Bouzon, M., Govindan, K., \& Rodriguez, C. M. T. (2018). Evaluating barriers for reverse logistics implementation under a multiple stakeholders' perspective analysis using grey decision making approach. Resources, Conservation and Recycling, 128, 315-35 doi:10.1016/j.resconrec.2016.11.022

Bouzon, M., Govindan, K., Rodriguez, C. M. T., \& Campos, L. M. S. (2016). Identification and analysis of reverse logistics barriers using fuzzy delphi method and ahp. Resources, Conservation and Recycling, 108, 182-97 doi:10.1016/j.resconrec.2015.05.021

Bowen, F. E., Cousins, P. D., Lamming, R. C., \& Farukt, A. C. (2001). The role of supply management capabilities in green supply. Production and Operations Management, 10(2), 174-89 doi:10.1111/j.19375956.2001.tb00077.x

Brix-Asala, C., Geisbüsch, A.-K., Sauer, P., Schöpflin, P., \& Zehendner, A. (2018). Sustainability tensions in supply chains: A case study of paradoxes and their management. Sustainability, 10(2), 424 doi:10.3390/su10020424

Bryman, A. (2003). Research methods and organization studies (Vol. 20): Routledge.

Carter, C., \& Rogers, D. (2008). A framework of sustainable supply chain management: Moving toward new theory. International Journal of Physical Distribution \& Logistics Management, 38(5), 360-87 doi:10.1108/09600030810882816

Carvalho, L. S. d., Stefanelli, N. O., Viana, L. C., Vasconcelos, D. d. S. C., \& Oliveira, B. G. (2020). Green supply chain management and innovation: A modern review. Management of Environmental Quality: An International Journal, 31(2), 470-82 doi:10.1108/MEQ-12-2019-0283

Chan, R. Y. K., Chan, H. K., He, H., \& Wang, W. Y. C. (2012). Environmental orientation and corporate performance: The mediation mechanism of green supply chain management and moderating effect of competitive intensity. Industrial Marketing Management, 41(4), 621-30 
doi:10.1016/j.indmarman.2012.04.009

Chiles, T. H., \& McMackin, J. F. (1996). Integrating variable risk preferences, trust, and transaction cost economics. The Academy of Management Review, 21(1), 73-99 doi:10.2307/258630

Da Silva, F. C., Shibao, F. Y., Barbieri, J. C., Librantz, A. F. H., \& Dos Santos, M. R. (2018). Barriers to green supply chain management in the automotive industry. RAE Revista de Administracao de Empresas, 58(2), 149-62 doi:10.1590/S0034-759020180204

Daddi, T., Ceglia, D., Bianchi, G., \& de Barcellos, M. D. (2019). Paradoxical tensions and corporate sustainability: A focus on circular economy business cases. Corporate Social Responsibility and Environmental Management doi:10.1002/csr.1719

Dhull, S., \& Narwal, M. S. (2016). Drivers and barriers in green supply chain management adaptation: A state-ofart review. Uncertain Supply Chain Management, 4(1), 61-76 doi:10.5267/j.uscm.2015.7.003

Diabat, A., \& Govindan, K. (2011). An analysis of the drivers affecting the implementation of green supply chain management. Resources, Conservation and Recycling, 55(6), 659-67 doi:https://doi.org/10.1016/j.resconrec.2010.12.002

Diabat, A., Khodaverdi, R., \& Olfat, L. (2013). An exploration of green supply chain practices and performances in an automotive industry. The International Journal of Advanced Manufacturing Technology, 68(1), 949-61 doi:10.1007/s00170-013-4955-4

Drohomeretski, E., Da Costa, S. G., \& De Lima, E. P. (2014). Green supply chain management: Drivers, barriers and practices within the brazilian automotive industry. Journal of Manufacturing Technology Management, 25(8), 1105-34 doi:10.1108/JMTM-06-2014-0084

Dube, A. S., \& Gawande, R. S. (2016). Analysis of green supply chain barriers using integrated ism-fuzzy micmac approach. Benchmarking, 23(6), 1558-78 doi:10.1108/BIJ-06-2015-0057

Elbarkouky, M. M. G., \& Abdelazeem, G. (2013). A green supply chain assessment for construction projects in developing countries. WIT Transactions on Ecology and the Environment, 179 VOLUME 2, 1331-41 doi:10.2495/SC131132

Elbarky, S., \& Elzarka, S. (2015). A green supply chain management migration model based on challenges faced in egypt.

Elbarky, S., \& Elzarka, S. (2015). A green supply chain management migration model based on challenges faced in egypt. Paper presented at the 2015 International Conference on Industrial Engineering and Operations Management (IEOM).

Elkington, J. (1998). Partnerships from cannibals with forks: The triple bottom line of 21 st-century business. Environmental Quality Management, 8(1), 37-51 doi:10.1002/tqem.3310080106

Emmett, S., \& Sood, V. (2010). Green supply chains: An action manifesto: John Wiley \& Sons.

Fang, S.-R., Chang, Y.-S., \& Peng, Y.-C. (2011). Dark side of relationships: A tensions-based view. Industrial Marketing Management, 40(5), 774-84

Geng, R., Mansouri, S. A., Aktas, E., \& Yen, D. A. (2017). The role of guanxi in green supply chain management in asia's emerging economies: A conceptual framework. Industrial Marketing Management, 63, 1-17

Ghadge, A., Kaklamanou, M., Choudhary, S., \& Bourlakis, M. (2017). Implementing environmental practices within the greek dairy supply chain drivers and barriers for smes. Industrial Management and Data Systems, 117(9), 1995-2014 doi:10.1108/IMDS-07-2016-0270

Govindan, K., Kaliyan, M., Kannan, D., \& Haq, A. N. (2014). Barriers analysis for green supply chain management implementation in indian industries using analytic hierarchy process. International Journal of Production Economics, 147, 555-68 doi:10.1016/j.ijpe.2013.08.018

Govindan, K., Madan Shankar, K., \& Kannan, D. (2016). Application of fuzzy analytic network process for barrier evaluation in automotive parts remanufacturing towards cleaner production - a study in an indian scenario. Journal of Cleaner Production, 114, 199-213 doi:10.1016/j.jclepro.2015.06.092

Govindan, K., Shankar, K. M., \& Kannan, D. (2020). Achieving sustainable development goals through identifying and analyzing barriers to industrial sharing economy: A framework development. International Journal of Production Economics, 227, 107575

Grekova, K., Bremmers, H. J., Trienekens, J. H., Kemp, R. G. M., \& Omta, S. W. F. (2014). Extending environmental management beyond the firm boundaries: An empirical study of dutch food and beverage firms. International Journal of Production Economics, 152, 174-87 doi:10.1016/j.ijpe.2013.12.019

Hahn, T., Pinkse, J., Preuss, L., \& Figge, F. (2015). Tensions in corporate sustainability: Towards an integrative framework. Journal of Business Ethics, 127(2), 297-316 doi:10.1007/s10551-014-2047-5

Helmy, O., Fayed, M., \& Hussien, K. (2018). Exchange rate pass-through to inflation in egypt: A structural var approach. Review of Economics and Political Science, 3(2), 2-19

Hervani, A. A., Helms, M. M., \& Sarkis, J. (2005). Performance measurement for green supply chain management. 12(4), 330-53 doi:doi:10.1108/14635770510609015

Heydari, J., Govindan, K., \& Basiri, Z. (2020). Balancing price and green quality in presence of consumer 
environmental awareness: A green supply chain coordination approach. International Journal of Production Research, 1-19 doi:10.1080/00207543.2020.1771457

Ivascu, L., Mocan, M., Draghici, A., Turi, A., \& Rus, S. (2015). Modeling the green supply chain in the context of sustainable development. Procedia Economics and Finance, 26, 702-08 doi:https://doi.org/10.1016/S2212-5671(15)00819-9

Jayant, A., \& Azhar, M. (2014). Analysis of the barriers for implementing green supply chain management (gscm) practices: An interpretive structural modeling (ism) approach. Paper presented at the Procedia Engineering.

Kaur, J., \& Awasthi, A. (2018). A systematic literature review on barriers in green supply chain management. International Journal of Logistics Systems and Management, 30(3), 330-48 doi:10.1504/IJLSM.2018.10013872

Kaur, J., Sidhu, R., Awasthi, A., Chauhan, S., \& Goyal, S. (2018). A dematel based approach for investigating barriers in green supply chain management in canadian manufacturing firms. International Journal of Production Research, 56(1-2), 312-32 doi:10.1080/00207543.2017.1395522

Lee, S.-Y. (2008). Drivers for the participation of small and medium-sized suppliers in green supply chain initiatives. Supply Chain Management: An International Journal, 13(3), 185-98

Liu, S., Eweje, G., He, Q., \& Lin, Z. (2020). Turning motivation into action: A strategic orientation model for green supply chain management. Business Strategy and the Environment doi:10.1002/bse.2580

Luthra, S., Garg, D., \& Haleem, A. (2013). Identifying and ranking of strategies to implement green supply chain management in indian manufacturing industry using analytical hierarchy process. Journal of Industrial Engineering and Management, 6(4), 930-62

Luthra, S., Kumar, V., Kumar, S., \& Haleem, A. (2011). Barriers to implement green supply chain management in automobile industry using interpretive structural modeling technique: An indian perspective. Journal of Industrial Engineering and Management, 4(2), 231 doi:10.3926/jiem.2011.v4n2.p231-257

Luthra, S., Mangla, S. K., Xu, L., \& Diabat, A. (2016). Using ahp to evaluate barriers in adopting sustainable consumption and production initiatives in a supply chain. International Journal of Production Economics, 181, 342-49 doi:10.1016/j.ijpe.2016.04.001

Majumdar, A., \& Sinha, S. (2018). Modeling the barriers of green supply chain management in small and medium enterprises: A case of indian clothing industry. Management of Environmental Quality: An International Journal, 29(6), 1110-22 doi:10.1108/MEQ-12-2017-0176

Majumdar, A., \& Sinha, S. K. (2019). Analyzing the barriers of green textile supply chain management in southeast asia using interpretive structural modeling. Sustainable Production and Consumption, 17, 176-87

Mathiyazhagan, K., Govindan, K., NoorulHaq, A., \& Geng, Y. (2013). An ism approach for the barrier analysis in implementing green supply chain management. Journal of Cleaner Production, 47, 283-97 doi:10.1016/j.jclepro.2012.10.042

Mathiyazhagan, K., Haq, A. N., \& Baxi, V. (2016). Analysing the barriers for the adoption of green supply chain management - the indian plastic industry perspective. International Journal of Business Performance and Supply Chain Modelling, 8(1), 46-65 doi:10.1504/IJBPSCM.2016.076000

Mathiyazhagan, K., Haq, A. N., Mohapatra, A., \& Srinivasan, P. (2017). Application of structural equation modelling to evaluate the barrier relationship for green supply chain management implementation. International Journal of Business Performance and Supply Chain Modelling, 9(2), 87-116 doi:10.1504/IJBPSCM.2017.085487

Mehrabi, J., Gharakhani, D., Jalalifar, S., \& Rahmati, H. (2012). Barriers to green supply chain management in the petrochemical sector. Life Science Journal, 9(4), 3438-42

Moktadir, M. A., Ali, S. M., Rajesh, R., \& Paul, S. K. (2018). Modeling the interrelationships among barriers to sustainable supply chain management in leather industry. Journal of Cleaner Production, 181, 631-51 doi:10.1016/j.jclepro.2018.01.245

Moktadir, M. A., Rahman, T., Rahman, M. H., Ali, S. M., \& Paul, S. K. (2018). Drivers to sustainable manufacturing practices and circular economy: A perspective of leather industries in bangladesh. Journal of Cleaner Production, 174, 1366-80 doi:https://doi.org/10.1016/j.jclepro.2017.11.063

Movahedipour, M., Zeng, J., Yang, M., \& Wu, X. (2017). An ism approach for the barrier analysis in implementing sustainable supply chain management: An empirical study. Management Decision, 55(8), 1824-50 doi:10.1108/MD-12-2016-0898

Mudgal, R. K., Shankar, R., Talib, P., \& Raj, T. (2010). Modelling the barriers of green supply chain practices: An indian perspective. International Journal of Logistics Systems and Management, 7(1), 81-107 doi:10.1504/IJLSM.2010.033891

Muduli, K., \& Barve, A. (2013). Establishment of a sustainable development framework in small scale mining supply chains in india. International Journal of Intelligent Enterprise, 2(1), 84-100 doi:10.1504/IJIE.2013.057340

Muduli, K., Govindan, K., Barve, A., \& Geng, Y. (2013). Barriers to green supply chain management in indian 
mining industries: A graph theoretic approach. Journal of Cleaner Production, 47, 335-44 doi:https://doi.org/10.1016/j.jclepro.2012.10.030

Nigam, P. (2014). Interpretive structural modelling (ism) of the barriers to green supply chain management in indian companies. International Journal of Business Performance and Supply Chain Modelling, 6(2), 183206 doi:10.1504/IJBPSCM.2014.062466

Oelze, N. (2017). Sustainable supply chain management implementation-enablers and barriers in the textile industry. Sustainability (Switzerland), 9(8) doi:10.3390/su9081435

Ozanne, L. K., Phipps, M., Weaver, T., Carrington, M., Luchs, M., Catlin, J., . . Williams, J. (2016). Managing the tensions at the intersection of the triple bottom line: A paradox theory approach to sustainability management. Journal of Public Policy and Marketing, 35(2), 249-61 doi:10.1509/jppm.15.143

Perotti, S., Micheli, G. J. L., \& Cagno, E. (2015). Motivations and barriers to the adoption of green supply chain practices among 3pls. International Journal of Logistics Systems and Management, 20(2), 179-98 doi:10.1504/IJLSM.2015.067255

Pressey, A. D., \& Vanharanta, M. (2016). Dark network tensions and illicit forbearance: Exploring paradox and instability in illegal cartels. Industrial Marketing Management, 55, 35-49 doi:https://doi.org/10.1016/j.indmarman.2016.02.009

Pumpinyo, S., \& Nitivattananon, V. (2014). Investigation of barriers and factors affecting the reverse logistics of waste management practice: A case study in thailand. Sustainability (Switzerland), 6(10), 7048-62 doi:10.3390/su6107048

Rahman, T., Ali, S. M., Moktadir, M. A., \& Kusi-Sarpong, S. (2019). Evaluating barriers to implementing green supply chain management: An example from an emerging economy. Production Planning \& Control, 31(8), 1-26 doi:10.1080/09537287.2019.1674939

Rao, P., \& Holt, D. (2005). Do green supply chains lead to competitiveness and economic performance? International Journal of Operations \& Production Management, 25(9), 898-916

Rauer, J., \& Kaufmann, L. (2015). Mitigating external barriers to implementing green supply chain management: A grounded theory investigation of green-tech companies' rare earth metals supply chains. Journal of Supply Chain Management, 51(2), 65-88 doi:10.1111/jscm.12063

Saaty, T. (1980). The analytic hierarchy process. Mcgrawhill international. New York

Saaty, T. L. (2008). Decision making with the analytic hierarchy process. International journal of services sciences, $1(1), 83-98$

Sajjad, A., Eweje, G., \& Tappin, D. (2015). Sustainable supply chain management: Motivators and barriers. Business Strategy and the Environment, 24(7), 643-55 doi:10.1002/bse.1898

Sajjad, A., Eweje, G., \& Tappin, D. (2019). Managerial perspectives on drivers for and barriers to sustainable supply chain management implementation: Evidence from new zealand. Business Strategy and the Environment, 29(2), 592-604 doi:10.1002/bse.2389

Samaras, G. D., Gkanas, N. I., \& Vitsa, K. C. (2014). Assessing risk in dam projects using ahp and electre i. International Journal of Construction Management, 14(4), 255-66

Sarkis, J., Zhu, Q., \& Lai, K.-h. (2011). An organizational theoretic review of green supply chain management literature. International Journal of Production Economics, 130(1), 1-15 doi:10.1016/j.ijpe.2010.11.010

Seman, N. A. A., Govindan, K., Mardani, A., Zakuan, N., Saman, M. Z. M., Hooker, R. E., \& Ozkul, S. (2019). The mediating effect of green innovation on the relationship between green supply chain management and environmental performance. Journal of Cleaner Production, 229, 115-27

Shibin, K. T., Gunasekaran, A., Papadopoulos, T., Dubey, R., Singh, M., \& Wamba, S. F. (2016). Enablers and barriers of flexible green supply chain management: A total interpretive structural modeling approach. Global Journal of Flexible Systems Management, 17(2), 171-88 doi:10.1007/s40171-015-0109-x

Shohan, S., Ali, S. M., Kabir, G., Ahmed, S. K. K., Haque, T., \& Suhi, S. A. (2020). Building theory of green supply chain management for the chemical industry: An emerging economy context. Management of environmental quality, 31(5), 1285-308 doi:10.1108/MEQ-11-2019-0239

Shrivastava, A. K., Kumara Swamy, S. K., Midathada, A., \& Ravella, U. K. (2017). Analysis of the barriers for implementing green supply chain management ( $\mathrm{gscm}$ ) practices on organic irrigation: An analytical hierarchy process (ahp) approach. International Journal of Mechanical Engineering and Technology, 8(7), 1465-73

Singh, R. K., Rastogi, S., \& Aggarwal, M. (2016). Analyzing the factors for implementation of green supply chain management. Competitiveness Review, 26(3), 246-64 doi:10.1108/CR-06-2015-0045

Sirisawat, P., \& Kiatcharoenpol, T. (2018). Fuzzy ahp-topsis approaches to prioritizing solutions for reverse logistics barriers. Computers and Industrial Engineering, 117, 303-18 doi:10.1016/j.cie.2018.01.015

Slawinski, N., \& Bansal, P. (2015). Short on time: Intertemporal tensions in business sustainability. Organization Science, 26(2), 531-49 doi:10.1287/orsc.2014.0960

Smith, W. K., \& Lewis, M. W. (2011). Toward a theory of paradox: A dynamic equilibrium model of organizing. The Academy of Management Review, 36(2), 381-403 doi:10.5465/AMR.2011.59330958 
Soda, S., Sachdeva, A., \& Garg, R. K. (2017). Barriers analysis for green supply chain management implementation in power industry using ism. International Journal of Logistics Systems and Management, 27(2), 225-59 doi:10.1504/IJLSM.2017.083820

Song, H., \& Gao, X. (2018). Green supply chain game model and analysis under revenue-sharing contract. Journal of Cleaner Production, 170, 183-92

Srivastava, S. K. (2007). Green supply-chain management: A state-of-the-art literature review. 9(1), 53-80 doi:doi:10.1111/j.1468-2370.2007.00202.x

Tóth, Z., Peters, L. D., Pressey, A., \& Johnston, W. J. (2018). Tension in a value co-creation context: A network case study. Industrial Marketing Management, 70, 34-45

Troisi, O. (2015). Green supply chain management. The TQM Journal, 27(2), 256-76

Tseng, M. L., Islam, M. S., Karia, N., Fauzi, F. A., \& Afrin, S. (2019). A literature review on green supply chain management: Trends and future challenges. Resources Conservation and Recycling, 141, 145-62 doi:10.1016/j.resconrec.2018.10.009

Tumpa, T. J., Ali, S. M., Rahman, M. H., Paul, S. K., Chowdhury, P., \& Khan, S. A. R. (2019). Barriers to green supply chain management: An emerging economy context. Journal of Cleaner Production, 236, 117617

Tura, N., Keränen, J., \& Patala, S. (2019). The darker side of sustainability: Tensions from sustainable business practices in business networks. Industrial Marketing Management, 77, 221-31 doi:https://doi.org/10.1016/j.indmarman.2018.09.002

Uddin, S., Ali, S., Kabir, G., Suhi, S., Enayet, R., \& Haque, T. (2019). An ahp-electre framework to evaluate barriers to green supply chain management in the leather industry. International Journal of Sustainable Development \& World Ecology, 26(8), 732-51

Vaidya, O. S., \& Kumar, S. (2006). Analytic hierarchy process: An overview of applications. European Journal of Operational Research, 169(1), 1-29 doi:https://doi.org/10.1016/j.ejor.2004.04.028

van Bommel, K. (2018). Managing tensions in sustainable business models: Exploring instrumental and integrative strategies. Journal of Cleaner Production, 196, 829-41

Van der Byl, C. A., \& Slawinski, N. (2015). Embracing tensions in corporate sustainability: A review of research from win-wins and trade-offs to paradoxes and beyond. Organization and Environment, 28(1), 54-79 doi: $10.1177 / 1086026615575047$

Walker, H., \& Jones, N. (2012). Sustainable supply chain management across the uk private sector. Supply Chain Management, 17(1), 15-28 doi:10.1108/13598541211212177

Wang, Z., Mathiyazhagan, K., Xu, L., \& Diabat, A. (2016). A decision making trial and evaluation laboratory approach to analyze the barriers to green supply chain management adoption in a food packaging company. Journal of Cleaner Production, 117, 19-28 doi:10.1016/j.jclepro.2015.09.142

Wooi, G. C., \& Zailani, S. (2010). Green supply chain initiatives: Investigation on the barriers in the context of smes in malaysia. International Business Management, 4(1), 20-27 doi:10.3923/ibm.2010.20.27

$\mathrm{Wu}, \mathrm{A} .$, \& Li, T. (2019). Gaining sustainable development by green supply chain innovation: Perspectives of specific investments and stakeholder engagement. Business Strategy and the Environment, 29(3), 962-75 doi: $10.1002 /$ bse. 2410

Xia, X., Govindan, K., \& Zhu, Q. (2015). Analyzing internal barriers for automotive parts remanufacturers in china using grey-dematel approach. Journal of Cleaner Production, 87(1), 811-25 doi:10.1016/j.jclepro.2014.09.044

Yang, Q., Geng, R., \& Feng, T. (2020). Does the configuration of macro - and micro - institutional environments affect the effectiveness of green supply chain integration? Business Strategy and the Environment, 29(4), 1695-713 doi:10.1002/bse.2462

Zhu, Q., \& Geng, Y. (2013). Drivers and barriers of extended supply chain practices for energy saving and emission reduction among chinese manufacturers. Journal of Cleaner Production, 40, 6-12 doi:10.1016/j.jclepro.2010.09.017

Zhu, Q., Sarkis, J., \& Geng, Y. (2005). Green supply chain management in china: Pressures, practices and performance. International Journal of Operations \& Production Management, 25(5), 449-68

Zhu, Q., Sarkis, J., \& Lai, K.-h. (2008). Confirmation of a measurement model for green supply chain management practices implementation. International Journal of Production Economics, 111(2), 261-73

Zhu, Q., Tian, Y., \& Sarkis, J. (2012). Diffusion of selected green supply chain management practices: An assessment of chinese enterprises. Production Planning \& Control, 23(10-11), 837-50 